Florida International University FIU Digital Commons

\title{
Attorney Decision Making in an Employment Discrimination Dispute Involving Personnel Selection
}

Erica N. Drew

Florida International University, edrew001@fiu.edu

DOI: $10.25148 /$ etd.FI1 1072515

Follow this and additional works at: https://digitalcommons.fiu.edu/etd

\section{Recommended Citation}

Drew, Erica N., "Attorney Decision Making in an Employment Discrimination Dispute Involving Personnel Selection" (2011). FIU Electronic Theses and Dissertations. 428.

https://digitalcommons.fiu.edu/etd/428 


\title{
FLORIDA INTERNATIONAL UNIVERSITY
}

Miami, Florida

\section{ATTORNEY DECISION MAKING IN AN EMPLOYMENT DISCRIMINATION DISPUTE INVOLVING PERSONNEL SELECTION}

\author{
A thesis submitted in partial fulfillment of the \\ requirements for the degree of \\ MASTER OF SCIENCE \\ in \\ PSYCHOLOGY
}

by

Erica N. Drew

2011 
To: Dean Kenneth Furton

College of Arts and Sciences

This thesis, written by Erica N. Drew, and entitled Attorney Decision Making in an Employment Discrimination Dispute Involving Personnel Selection, having been approved in respect to style and intellectual content, is referred to you for judgment.

We have read this thesis and recommend that it be approved.

$\begin{array}{r}\hline \text { Victoria Pace } \\ \hline \text { Ryan Winter } \\ \hline \text { Chockalingam Viswesvaran, Major Professor }\end{array}$

Date of Defense: May 16, 2011

The thesis of Erica N. Drew is approved.

\begin{tabular}{r}
$\begin{array}{r}\text { Dean Kenneth Furton } \\
\text { College of Arts and Sciences }\end{array}$ \\
\hline Interim Dean Kevin O'Shea \\
University Graduate School
\end{tabular}

Florida International University, 2011 
ABSTRACT OF THE THESIS

ATTORNEY DECISION MAKING IN AN EMPLOYMENT DISCRIMINATION

DISPUTE INVOLVING PERSONNEL SELECTION

by

Erica N. Drew

Florida International University, 2011

Miami, Florida

Professor Chockalingham Viswesvaran, Major Professor

A national sample of attorneys $(N=134)$ was surveyed to investigate how characteristics of a rejected applicant's claim would affect subsequent claimant outcomes and appraisals. Equal Employment Opportunity Commission (EEOC) merit determinations positively influenced attorney representation decisions and confidence in favorable claimant outcomes. Attorneys found rejected applicant claims more credible when the claimant perceived the selection procedure to be unrelated to the target position and when the applicant was a racial minority. Attorney course of legal action was dependent on the interaction of both EEOC decision and applicant perceptions of job relatedness, such that more claimant supportive actions were observed when the EEOC found merit and the applicant perceived the selection procedures to be job unrelated. The impact of organizational efforts in validation, scoring procedures, and adverse impact reduction were explored in regard to settlement and litigation outcomes. Exploratory analyses identified best practices in regard to these issues. 


\section{TABLE OF CONTENTS}

CHAPTER $\quad$ PAGE

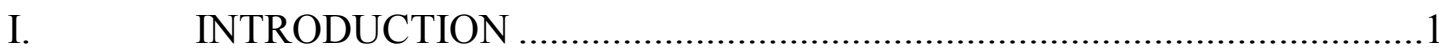

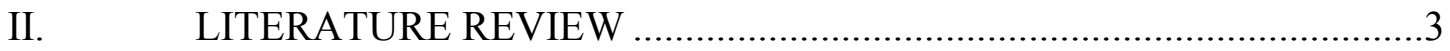

Personnel Selection .............................................................................

EEO Litigation and Legal Discrimination Theory.......................................14

EEOC Claims Process and Statistical Trends ...........................................21

I/O Science vs. Legal Practice: Ambiguities in the EEO Landscape .........25

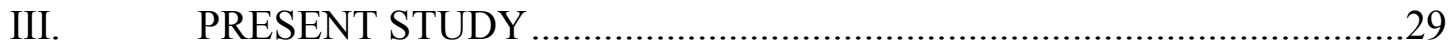

Protected Group Category.......................................................................... 31

Aggravating and Mitigating Factors ………………………….................. 32

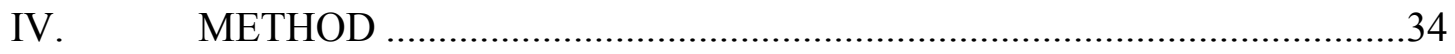

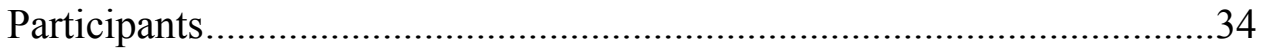

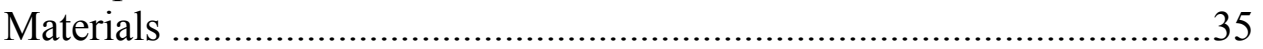

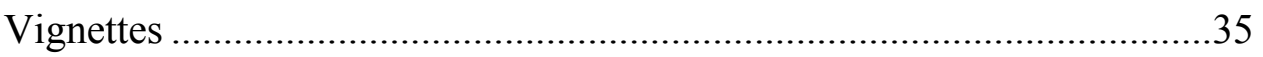

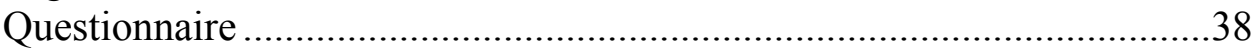

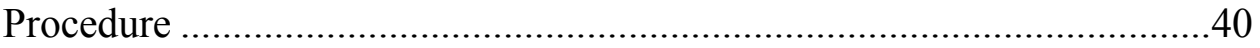

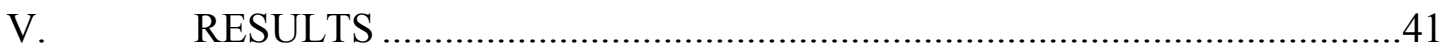

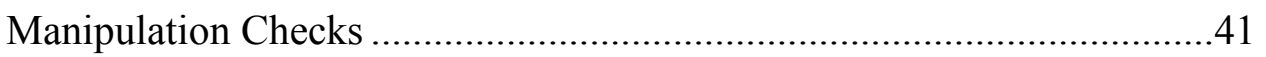

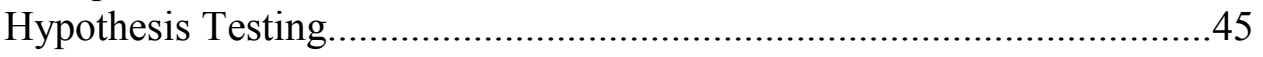

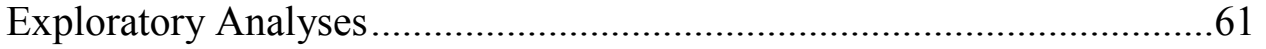

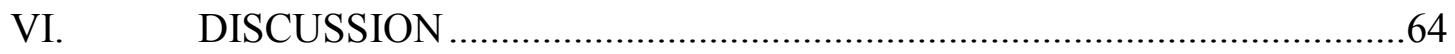

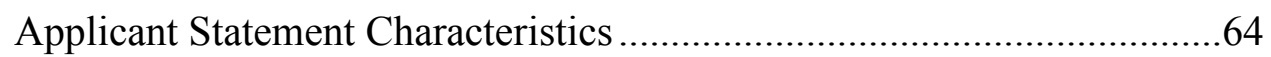

Organizational Evidence: Results and Best Practices.................................68

Limitations and Future Directions .........................................................70

Implications and Conclusions ...................................................................72

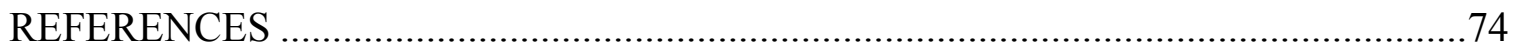

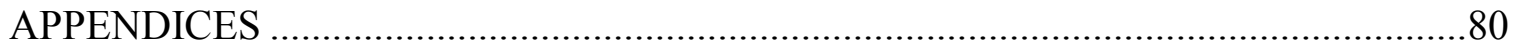




\section{LIST OF TABLES}

TABLE

PAGE

1. Strategies for Reducing Adverse Impact and Subgroup Differences

2. Total Number and Percentage of Title VII EEOC Charges Filed in 2009 by Basis

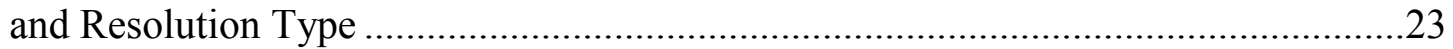

3. Summary of Dependent Variable Intercorrelations .............................................45

4. Analysis of Variance Cell Means: Representation ................................................46

5. Analysis of Variance Cell Means: Confidence ........................................................48

6. Analysis of Variance Cell Means: Credibility ....................................................49

7. Frequency Distribution for Course of Legal Action Outcomes by Condition ............51

8. Analysis of Variance Cell Means: Course of Legal Action........................................51

9. Descriptive Summary of EEOC Decision Simple Main Effects: Course of Legal Action.

10. Descriptive Summary of Job Relatedness Simple Main Effects: Course of Legal

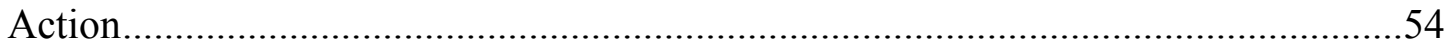

11. Analysis of Variance Cell Means: Perceptions of Rejected Applicant Aggregate......56

12. Analysis of Variance Cell Means: Rejected Applicant Outcomes Aggregate.....

13. Descriptive Summary of EEOC Decision Simple Main Effects: Rejected Applicant Outcomes Aggregate

14. Descriptive Summary of Job Relatedness Simple Main Effects: Rejected Applicant Outcomes Aggregate.

15. Rank Order of Validation, Scoring and Adverse Impact Reduction Strategy Scores by Monetary Compensation Request in Settlement and Desire to Pursue Litigation 


\section{INTRODUCTION}

Fostering a competent and diverse workforce is essential to many principal organizational functions (Ployhart \& Holtz, 2008). With the extant diverse applicant pool, organizations must take caution in maintaining inclusive and nondiscriminatory personnel selection practices or risk significant monetary costs due to regulatory enforcement or litigation (EEOC, 2009a). In 2009, 93,277 workplace discrimination claims were filed with the Equal Employment Opportunity Commission (EEOC); one of the highest levels of claiming activity ever recorded. Beyond the high level of claiming activity, monetary compensation for these cases totaled over \$376 million (EEOC, 2009a).

The consequences incurred by an organization charged with discrimination, however, go far beyond financial loss. In fact, organizations with such "chilling" reputations may find it more difficult to attract, recruit, hire, and retain a diverse and high quality workforce. Further, negative public perceptions of the organization may decrease demand for products or services, and in particularly egregious circumstances, lower the value of an organization's stock (Cascio, 2000). Though there are some organizations that make blatant discriminatory personnel decisions, the majority put forth a "good faith effort" to support and sustain diversity through well-intentioned selection practices and still get sued (Biddle, Kuthy \& Nooren, 2003). Situations such as these are often a result of adverse impact or differential passing rates for members of racial, ethnic, and sex subgroups in the personnel selection context.

Decision-making in personnel selection involves a delicate trade off between development of legally defensible selection procedures and selection of the best-qualified 
candidates for employment. Unfortunately, some of the most valid predictors of job performance (e.g., cognitive ability) have also been associated with the highest potential for adverse impact on race and sex subgroups. Pyburn, Ployhart, and Kravitz (2008) coined this issue as the diversity-validity dilemma, wherein organizations must choose between workplace diversity and optimal valid prediction. Further, previous research has indicated that organizational perceptions of the legal risks associated with certain types of selection devices do not always represent actual risk. For example, an organization may choose to implement a selection procedure perceived to be legally defensible rather than a validated procedure incorrectly perceived to have higher legal risk (Terpstra, Mohamed \& Kethley, 1999).

Given the potentially crippling consequences of employment discrimination litigation, the creation of legally defensible selection processes has received much attention from industrial/organizational (I/O) psychologists and legal scholars alike (e.g., Biddle et al., 2003; Terpstra et al. 1999; Williamson, Campion, Malos, Roehling \& Campion, 1997). Most of this research has been devoted to fostering positive applicant perceptions of selection procedures (e.g., Ryan \& Ployhart, 2000), and developing strategies to reduce adverse impact (e.g., Ployhart \& Holtz, 2008; Ryan \& Tippins, 2004).

The Supreme Court has not ruled on adverse impact since its controversial decision in Wards Cove v. Antonio (1989), made over 20 years ago. In Wards Cove the traditional adverse impact judicial scenario was altered by a plurality opinion but later returned to its original composition with the passing of the Civil Rights Act of 1991 (CRA-91). As a result of the lack of judicial review, the current legal landscape is wrought with ambiguities and unanswered questions regarding several important 
personnel selection issues (Gutman, 2009). Attorneys are essentially litigation gatekeepers and thus an untapped resource with respect to these unresolved issues. By gaining insight into the process by which attorneys evaluate key pieces of evidence to make decisions in employment discrimination cases, the field of I/O psychology may realize some resolution to the established uncertainties in the personnel selection arena. The purpose of the present thesis was to further inform professional discretion in personnel selection and perhaps decrease the probability of employment discrimination litigation by examining how attorneys come to make the decision to (a) represent a rejected applicant, and (b) determine monetary compensation and litigation outcomes based on reported organizational efforts made in test construction and validation.

The present thesis will be divided in to five major chapters. First, personnel selection and the key legal issues involved will be discussed in the literature review. The second chapter will introduce thesis hypotheses and their empirical rationale. The third chapter will present study methodology and discuss vignettes and questionnaire used to investigate hypotheses. The fourth chapter will outline results of hypothesis testing and exploratory analyses. Finally, key findings, limitations and future directions will be presented in the discussion.

\section{LITERATURE REVIEW}

The following literature review is divided into four main sections, each representing a major topic area. The first section presents general information and key concepts in regard to personnel selection in organizations. The second section introduces legal discrimination theories and corresponding judicial scenarios, as well as landmark cases and legislation in regard to personnel selection. The third section outlines the 
typical life-cycle of a claim filed with the Equal Employment Opportunity Commission (EEOC) and current data trends in regard to discrimination claims filed with this regulatory agency are outlined. In the fourth section a comparison of Industrial/Organizational (I/O) science and legal practice is utilized to illustrate several key ambiguities within the larger Equal Employment Opportunity (EEO) landscape.

\section{Personnel Selection}

Personnel selection is a systematic process by which individuals in a relevant applicant pool are matched to a specific job through a selection procedure. Selection procedure refers to any process used in personnel decision-making including various types of: (1) test administration methods (e.g., traditional paper and pencil, assessment centers, work sample); (2) content areas (e.g., cognitive, ability, personality); and (3) processes (e.g. job performance appraisals, and estimates of potential). Personnel selection utilizes evidence-based techniques to determine the most qualified candidate from a pool of applicants. The goal of personnel selection is to use evidence collected from the selection procedure to make accurate predictions of applicant future performance.

Accurate prediction of job performance is the cornerstone of successful selection outcomes and is instrumental to both legal defensibility and competitive advantage. Accurate prediction rests on two distinct qualifications: (1) job analysis, and (2) validation. Job analysis is the process that identifies important job tasks, necessary employee behaviors and organizational standards of performance in order to develop accurate predictors (Ployhart, Schnider \& Schmitt, 2006) Validation is the means by which accurate prediction is substantiated (Van Iddekinge \& Ployhart, 2008). 
Three authoritative guidelines are available to align selection procedure decisionmaking with industry and regulatory standards: (1) the Standards for Educational and Psychological Testing (American Educational Research Association, American Psychological Association, \& National Council on Measurement, 1999) (Standards), (2) the Principles for the Validation and Use of Personnel Selection Procedures (Society for Industrial and Organizational Psychology, 2003) (Principles), and (3) the Uniform Guidelines on Employee Selection Procedures (1978) (Uniform Guidelines). The following sections will discuss important aspects of personnel selection with regard to definitions from all three authoritative sources.

Job Analysis. Job analysis is the foundation of many organization functions, including the selection decision-making processes. In order to accurately match desirable candidates to a target position, an employer must first understand what specific work tasks are performed on the job as well as the knowledge, skills, abilities and other characteristics (KSAO's) that are required in order to perform these tasks. The Principles define job analysis as a "method used to gain an understanding of the work behaviors and activities required, or the worker requirements (e.g., KSAOs), and the context or environment in which an organization and individual may operate" (p.66). Using information documented in the job analysis, professionals can determine which job performance predictors are critical to measure within the selection procedure. For example, if customer service is identified as a critical component of a retail job, the selection test should include a method to measure this ability. To ensure accurate prediction of job performance, predictors should be chosen by careful consideration of the information presented in a job analysis. 
Validity. Demonstrable validity of both individual predictors and/or the aggregate of multiple predictors are required to ensure the prediction of performance is both accurate and comprehensive (Ployhart et al., 2006). In general, if a selection procedure is valid it means that the information obtained through the measurement of predictors is appropriate, meaningful, and useful for interpretation of test scores and subsequent decision-making. According to the Standards, "Validity is the most important consideration in developing and evaluating selection procedures" (p. 4). Valid selection procedures have been found to increase individual and organizational performance (Schmidt \& Hunter, 1998) and promote legal defensibility. In fact, properly validated selection procedures are more likely to withstand legal scrutiny in EEO disputes and may even decrease the likelihood of litigation all together (Sharf \& Jones, 2000). Further, validity is arguably the most critical consideration for test developers and users because demonstrated validity satisfies the employer burden of proof in EEO litigation proceedings involving adverse impact. This process is discussed in more detail later in this chapter.

The Standards and Principles present validity as a unitary concept that incorporates evidence from multiple sources including (but not limited to) test content, internal structure, response processes, consequences of testing, and relationships to other variables (see Jeanneret, 2005 and Osterlind, 2006, Chapter 4 for substantive review). These lines of evidence are not discussed in the Uniform Guidelines because they were unidentified at the time of its publication. Three principle sources of evidence for making inferences about validity are emphasized in the Uniform Guidelines: content-related evidence, criterion-related evidence, and construct-related evidence. It is important to 
distinguish between these sources because the evidence provided influences the type of inferences that can be drawn (Cascio \& Aguinis, 2005, Chapter 7) and further, holds differential implications in legal proceedings (Gutman, 2005).

Content-related evidence. Content-related evidence is concerned with whether or not predictor content provides a representative sample of the criterion domain. All three authorities agree with this definition, though the Uniform Guidelines tend to be more dismissive of the concept in regard to the measurement of traits or constructs. Though content-related evidence is considered to be primarily concerned with inferences about test construction rather than inferences about test scores, its importance should not be dismissed (Cascio \& Aguinis, 2005, Chapter 7). In situations where there is not an adequate sample for a criterion study, or insufficient or unreliable criterion measures, content-related evidence may be the only option (Jeanneret, 2005). Further, content validity is valuable in later criterion measurement, and holds implications for the establishment of criterion-related validity (Cascio \& Aguinis, 2005, Chapter 7).

Construct-related evidence. Construct-related evidence is concerned with whether or not the interpretation or meaning of predictor scores measure the target construct. In other words, it must be shown that a predictor is measuring the claimed construct. Specifically, predictor measures should be related to scores on others measures of the same construct (convergent validity) and unrelated to scores on measures of irrelevant constructs (discriminant validity).

Where content-related evidence is concerned with the ability of test items to measure KSAOs, construct-related evidence is concerned with the extent to which the test measures a specific construct determined to be critical for job performance. Thus, the 
essential function of construct-related evidence is to provide the evidential basis for the interpretation of test scores. The Standards and Principles define construct validity as being synonymous with validity, such that all selection procedure scores or outcomes are viewed as measure of a particular construct. Again, the Uniform Guidelines treat construct validity as a separate type of validity (Jeanneret, 2005).

Criterion-related evidence. Criterion-related evidence is concerned with whether or not test scores are predictive of important elements of job performance for some criterion measure (Cascio \& Aguinis, 2007, Chapter 7). Criterion-related validity is established by: (1) collecting scores on predictors of interest, (b) measuring job performance criteria and (3) correlating the predictor(s) and the criteria. Criterion-related evidence demonstrates the empirical relationship between predictor scores and criterion scores. The resulting empirical relationship supports the validity of the predictor or combination of predictors in inferring individual standing on a particular criterion. Criteria can be measured at the same time as predictor scores (concurrent design) or sometime after predictor scores have been determined (predictive design).

Valid inferences regarding test scores involve evaluation of evidence pertaining to the content of the selection procedure, specifically the predictor content domain or the latent construct being measured (Osterlind, 2006, Chapter 4). In general, the level of abstraction associated with behaviors in the criterion domain is used to determine which type of evidence is most appropriate (Cascio \& Aguinis, 2005, Chapter 7). Contentrelated evidence is most appropriate for observable behaviors (e.g., job knowledge, work sample performance) whereas construct-related evidence is most appropriate for more abstract behaviors (e.g., personality traits, cognitive ability). The Uniform Guidelines 
support this distinction and even go so far as to prohibit the use of content-related evidence in the validation of traits or constructs (Jeanneret, 2005). However, because most observable behaviors still involve an inference about an underlying construct on which individuals differ, one would be ill-advised to assume that complete dismissal of content-related validity is appropriate (Cascio \& Aguinis, 2005, Chapter 7; Jeanneret, 2005). In fact, validation research has suggested that content-related validity can be considered a prerequisite to construct-related validity (Schriesheim, Powers, Scandura, Gardiner, \& Lankau, 1993). Though validity evidence is critical to substantiating use of selection tests, it alone cannot negate the threat of adverse impact to the legal defensibility of a selection system.

Discrimination in personnel selection decision-making: Actual vs. perceived. Discrimination can be perceived by the job applicant or determined by statistical procedures. Applicant perceptions of discrimination can be managed by ensuring procedure content is related to the job, non-invasive and administered consistently (Gilliland, 1994; Ryan \& Ployhart, 2000; Smither, Reilly, Millsap, Pearlman \& Stoffey, 1993). In order to show procedures are not actually discriminatory to particular subgroups, users of selection measures must statistically investigate subgroup differences in the prediction of job performance. Subgroup differences can be observed in (1) criterion - predictor regression line slopes, (2) criterion - predictor regression line intercepts and (3) criterion and/or predictor score means.

The concept of subgroup differences is closely related to the concept of bias. The Standards define bias as any source of construct-irrelevant source of variance that produces differential outcomes for applicant subgroups. Thus, a biased test is one in 
which systematic differences in the meaning of tests scores are associated with group membership. Both the Standards and the Principles define predictive bias as "the systematic under- or over-prediction of criterion performance for people belonging to groups differentiated by characteristics not relevant to criterion performance" (p. 70). For example, though a majority and minority applicant may receive similar scores on a cognitive ability test, the minority applicant may in actuality possess a higher level of cognitive ability than indicated by the predictor.

In the employment context, an analysis of predictive bias is required to determine if such bias is present. In general, if the expected value of a regression error term is not zero (non-zero error) and these non-zeros errors are consistent, one can conclude that predictive bias is present. The most comprehensive method is the Cleary Test of Bias (Cleary, 1968), in which possible differences between the slopes, intercepts and standard error of estimate of subgroup regression lines are assessed to determine if predictive bias exists. If a measure predicts performance differently for subgroups but is still used across applicants then the measure may unfairly discriminate against the subgroup for which the measure is less valid. Unfair discrimination represents a false assumption that inferior test performance translates to inferior job performance when predictive bias is present (Guion, 1966).

Mean differences in predictor scores across subgroups are particularly concerning because they can result in substantial differences in hiring rates across subgroups of applicants (Ployhart et al., 2006). Where predictive bias involves differences in performance prediction across subgroups, adverse impact involves differences in the rate at which applicants across subgroups are hired. Adverse impact occurs when a facially 
neutral selection procedure predicts performance differentially for members of different subgroups, such that members from one group (majority) are selected at a higher rate than members of the other group (minority). As noted in the Uniform Guidelines, adverse impact refers to a situation where the selection rate for a protected group is less than $4 / 5$ th or $80 \%$ of the rate for the majority group. Adverse impact is illegal if the differences are unrelated to success on the job. Thus, illegal adverse impact occurs when subgroup differences result in differential hiring outcomes across subgroups.

In anticipation of legal and societal consequences, as well as regulatory enforcement, I/O professionals have developed and tested various strategies for reducing adverse impact and subgroup differences. Table 1 illustrates several common examples of these strategies (see Ryan \& Tippins, 2004 and Ployhart \& Holtz, 2008 for more substantive review). These strategies range from statistical procedures, recommended combinations of predictors and methods to encourage favorable applicant's perceptions of selection procedures.

Applicant perceptions of selection procedures represent an extensive research area that considers the impact of test content and outcomes on applicant attitudinal outcomes (e.g., Bauer et. al., 1998; Gilliland, 1994; Viswesvaran \& Ones, 2004). This research integrates work from the motivational theory of organizational justice, including implications for attitudes resulting from the perceived fairness of procedures and processes (procedural justice) and fairness of outcomes resulting from such procedures (distributive justice; Colquitt, Conlon, Wesson, Porter \& Ng, 2001; Gilliland, 1993). Applicant reactions are an important consideration for test users given that negative perceptions may produce adverse outcomes for both the individual applicant (i.e., self- 
efficacy; Truxillo, Bauer, Campion \& Paronto, 2006) and the organization (i.e., reputation and attractiveness; Ryan \& Ployhart, 2000). Specifically, perceptions of test content job relatedness have been studied extensively in previous research passed on the premise that applicant will perceive selection procedures more favorably to the extent that techniques are perceived as face valid and predictive of job performance. Job relatedness was conceptualized by Smither et al. (1993) as a two-factor construct comprised of face validity and perceived predictive validity. Face validity is "the extent to which applicants perceive the content of the selection procedure to be related to the content of the job" (Smither et al., 1993, p.54). For example, an applicant who found a test to be face valid would perceive that the content to the test was clearly related to the target position. Perceived predictive validity is "how well the procedure predicts future job performance, regardless of how it looks" (Smither et al., 1993, p.54). For example, an applicant who perceived predictive validity would conclude that a person who did well on the test would do well on the job. Both factors have been found to be strong predictors of applicant perceptions of procedural and distributive justice and attitudes towards tests in general (Hauskecht, Day \& Thomas, 2004). Further, face validity has demonstrated a negative relationship with test-taking motivation (Cascio, 1987). In terms of legal outcomes, some research has indicated that if a selection procedure is perceived to be job related the applicant will be less likely to file a legal suit (Thibodeaux \& Kudisch, 2003). In summary, because adverse impact may occur when no unfair discrimination exists, I/O professionals must make every effort to ensure personnel selection procedures are without bias both statistically and in regard to applicant reactions to avoid legal scrutiny. Thus, it appears the best way to avoid allegations of discrimination is to produce 
Table 1

Strategies for Reducing Adverse Impact and Subgroup Differences

\begin{tabular}{|c|c|}
\hline Strategy & Rationale \\
\hline $\begin{array}{l}\text { Use cognitive predictors } \\
\text { in conjunction with } \\
\text { noncognitive predictors }\end{array}$ & $\begin{array}{l}\text { The largest subgroup differences in mean scores exist for } \\
\text { measures of cognitive abilities. Thus, by including } \\
\text { measures of noncognitive abilities such as personality or } \\
\text { structured interviews adverse impact can be reduced. }\end{array}$ \\
\hline $\begin{array}{l}\text { Use specific cognitive } \\
\text { abilities vs. general } \\
\text { cognitive abilities }\end{array}$ & $\begin{array}{l}\text { Mean differences are smaller for subgroups when specific } \\
\text { cognitive abilities are measured. }\end{array}$ \\
\hline $\begin{array}{l}\text { Give less weight to task } \\
\text { performance predictors }\end{array}$ & $\begin{array}{l}\text { Contextual performance (e.g., reliability, helping } \\
\text { coworkers) has less cognitive components than particular } \\
\text { aspects of task performance. }\end{array}$ \\
\hline $\begin{array}{l}\text { Use a multiple hurdle } \\
\text { approach, with less } \\
\text { adverse methods first }\end{array}$ & $\begin{array}{l}\text { If the selection ratio is low, using methods with less } \\
\text { adverse impact in early stages, and methods with higher } \\
\text { adverse impact later on will assist in minority hiring. }\end{array}$ \\
\hline Use test score banding & $\begin{array}{l}\text { Substantial reduction of adverse impact will occur when } \\
\text { minority preference within a band is employed. }\end{array}$ \\
\hline $\begin{array}{l}\text { Use alternative test } \\
\text { stimuli presentation } \\
\text { modes }\end{array}$ & $\begin{array}{l}\text { Paper-and-pencil test administration typically involves } \\
\text { heavy verbal and reading components. Use of such } \\
\text { presentation formats may result in subgroup differences. } \\
\text { Using alternative formats such as situational judgment or } \\
\text { video-based tests may reduce adverse impact. }\end{array}$ \\
\hline Enhance face-validity & $\begin{array}{l}\text { Face validity concerns the degree to which test takers } \\
\text { perceive the test to be valid. By increasing the perceptions } \\
\text { of test validity, perceptions of injustice may be reduced. }\end{array}$ \\
\hline $\begin{array}{l}\text { Employ a targeted } \\
\text { recruitment strategy }\end{array}$ & $\begin{array}{l}\text { By targeting qualified minorities in recruitment, } \\
\text { characteristics of the applicant pool will be more } \\
\text { supportive of diversity and less susceptible to adverse } \\
\text { impact. }\end{array}$ \\
\hline
\end{tabular}

Note. The presented strategies were complied from information provided by Cascio \& Aguinis (2005), Ryan \& Tippins (2004), and Ployhart \& Holtz (2008). 
unbiased and valid tests rather than trading validity for methods found to result in less adverse impact for minority applicants. The next section begins with a discussion of legal theories of discrimination and their respective judicial scenarios. Then, the history of legal and statutory authority of EEO issues is discussed. The process of filing a discrimination claim with a regulatory agency is presented. Finally, professional and legal ambiguities in the EEO landscape are introduced.

\section{EEO Litigation and Legal Discrimination Theory}

The societal climate during the Civil Rights Movement in the 1960s brought to light the need for a formalized requirement of civil equality for various minority groups in the workplace. Title VII of the Civil Rights Act of 1964 made it unlawful for an employer to discriminate against an employee or applicant for employment or promotion because of their membership in a protected group. Protected groups are defined by race, color, sex, national origin and religion. Under this legislation, any member of a protected group could pursue litigation to remedy employment discrimination. After the establishment of Title VII, many court cases involving disparate selection procedures entered courtrooms at both the state and federal level. The decisions made in these cases initiated the establishment of subsequent legal precedent, legislation, and professional guidelines regarding employment discrimination.

Two distinct theories of discrimination fall under Title VII provisions: disparate treatment and disparate impact. The main difference between the two theories is (1) the employer's intent or motive to discriminate, and (2) the burden of proofs on the plaintiff and defendant (also known as a judicial scenario). A disparate treatment case requires the plaintiff to establish that the employer purposefully treated an individual, or several 
individuals, differently on the basis of their race, sex, national origin, or age. A disparate (or adverse) impact case requires the plaintiff to establish an organization's practice, procedure, or test had adverse impact on their protected group, regardless of whether there was intent to discriminate. These cases involve personnel selection and promotion procedures that appear neutral on their face, but result in discriminatory outcomes such as lower passing rates for protected groups. Most organizations are well intentioned and do their best to comply with non-discriminatory best practices in personnel selection. As seen in the cases of adverse impact, even well intentioned organizations may be accused of discriminatory procedures. Thus, the present study considers disparate impact and attorney decisions made regarding applicants who suspect such discrimination absent of blatant differential treatment.

Monetary compensation in a disparate impact case is based on a "make-whole" principle, limited to equitable reimbursement, whereas individuals claiming disparate treatment may seek both compensatory and punitive damages. Further, while disparate impact cases are decided solely by a judge, disparate treatment cases may be decided by a jury. The following section will discuss two unique attributes of adverse impact: (1) its unique judicial scenario and (2) relationship with legal precedent, and statutory and regulatory law (Gutman, 2005).

Adverse impact judicial scenario. There are three phases in an equal employment opportunity (EEO) case involving adverse impact in which burdens of proof are shifted from the plaintiff to the defendant. The trial can conclude at any phase if a particular party is able to meet their burden of proof and the opposing party is unable to successfully rebut evidence presented by the opposing party. 
Prima facie (plaintiff). In the first phase of the adverse impact judicial scenario, the plaintiff must provide prima facie evidence of a Title VII violation. Prima facie refers to a legal suit wherein the plaintiff presents evidence sufficient to prove that the employer used a discriminatory procedure and the defendant is unable to present significant contradictory evidence. In the case of disparate impact, the plaintiff must establish, by a preponderance of the evidence, that the employer used a particular employment practice that caused adverse impact to a protected group. To meet this burden, the plaintiff must identify the cause(s) of adverse impact, demonstrate that a disparity exists and establish a casual relationship between the cause and the disparity by providing statistical proof. In terms of statistical evidence, a test is determined to have disparate impact if the difference between subgroups is statistically significant and the impact is great enough to hold practical significance (Siskin \& Trippi, 2005).

Burden of persuasion (defendant). Once the plaintiff establishes a prima facie case, the burden shifts to the defendant to show that the selection procedure used was related to the job the plaintiff applied for and justified by business necessity. Demonstrated validity at this stage satisfies both prongs of this evidential requirement. The defense may also rebut the plaintiff's statistical proof at this stage by providing more accurate, valid, or reliable statistical evidence.

Typically in matters of content or construct validity the precedent set in Guardians of New York v. Civil Service Commission (1980) is upheld. In Guardians, a 5point test was introduced to determine the quality and standards of an employment test in question. First, there must be presence of a suitable job analysis. Second, reasonable competence in test construction must be demonstrated by the test developer. Third, the 
content of the test must be related to the content of the job. Fourth, the test content must be representative of the job and the procedure and methodology of test administration must be similar to the procedures required by the job itself. Lastly, the scoring system must successfully select applicants who can perform better on the job than those applicants disqualified.

Demonstration of pretext (plaintiff). If the employer is successful demonstrating a burden of persuasion, the plaintiff must prove that an alternative procedure exists to serve the employer's legitimate purpose without causing adverse impact. Further, this suggested practice must be equally valid and job-related.

Disparate treatment judicial scenarios. There are two additional judicial scenarios relevant to EEO litigation that are generally applied in cases involving disparate treatment and involve a similar burden-shifting framework: the McDonnell-Burdine scenario and pattern or practice. The McDonnell-Burdine scenario applies to case-by-case (or individuous) claims of disparate treatment wherein the plaintiff claims intentional exclusion and the employer claims a legitimate motive for the exclusion that would preclude any member of a protected group. The scenario was first introduced in McDonnell Douglas v. Green (1973) and was later confirmed in Texas Department of Community Affairs v. Burdine (1981). Pattern or practice involves an employer's standard operating procedure that simultaneously mistreats many members of a protected group. Though pattern or practice often involves statistical disparities it should not be confused with circumstances involving disparate impact. Disparate impact includes applicant-flow disparities, where pattern or practice involves disparities in the 
composition of a workforce and relevant labor pool or across jobs (e.g., only whites in upper-level jobs and only minorities in lower-level jobs).

The composition of the disparate treatment judicial scenario raises the bar on the burden requirements for the plaintiff, presumably to compensate for the required demonstration of intent to discriminate. Namely, the employer is only required to articulate a legitimate reason for the selection decision made. This requirement is known as a burden of production, and unlike the burden of persuasion requirement in the disparate impact tradition, the employer in a disparate treatment case does not have to present validation evidence.

From Griggs to CRA-91: The history of adverse impact. The adverse impact judicial scenario was established by the Supreme Court in two landmark cases: Griggs v. Duke Power (1971) and Albemarle Paper Company v. Moody (1975). In 1978, the Uniform Guidelines were written to interpret Griggs and Albemarle. In 1991, adverse impact was codified by Title VII of the Civil Rights Act of 1991 (CRA-91) to overturn the controversial decision made by the Court in Wards Cove v. Antonio (1989). The judicial review in these cases marked the development of the burden shifting framework now seen in employment discrimination civil trials.

In Griggs, black workers brought suit against Duke Power for requiring employees seeking promotion to meet diploma and testing requirements. Though the diploma requirement was instituted ten years prior, there was no evidence to support the assumption that white upper-level workers with a diploma performed any better than whites without a diploma. Thus, the new requirements were believed to be unrelated to job performance. Further, adverse impact evidence in the form of differential passing 
rates $(58 \%$ whites vs. $6 \%$ blacks) and high school graduation rates ( $34 \%$ whites vs. $12 \%$ blacks) demonstrated both requirements to be discriminatory.

Initially, lower courts agreed with Duke Power, citing statutory language of Title VII to support their claim that "professionally developed ability tests" not intended to discriminate against a protected group were legal. The Supreme Court unanimously disagreed, and relied on the definition of "professionally developed ability tests" given in the 1966 Uniform Guidelines that required such a test to measure the knowledge, skills and abilities relevant to the specific job the applicant applied for. Further, the opinion written by Justice Burger made clear that assuming unintentional discriminatory practices are legal under Title VII is explicitly incorrect. Thus, the intent requirement assumed in the lower courts was dismantled and Title VII provisions were expanded to cover discriminatory "consequences of employment practice, not simply the motivation" of employers (Gutman, 2005).

Following the Griggs ruling, it became apparent to many employers that selection instrument validation was paramount to legal defensibility. Albemarle Paper Company's efforts to validate the two cognitive tests in use at that time fell far from adequate. The company hired an external consultant to conduct a criterion validation study four months prior to trial. Evidence indicated the consultant had visited the organization for a half-day and solely created and implemented a validation strategy, thus demonstrating Albemarle was perhaps unaware that the employed selection procedures resulted in adverse impact. The defendants won in the lower courts for the same reason Duke Power made it through in Griggs — the court found insufficient evidence that the adverse impact was intentional. The second circuit and the Supreme Court overturned the decision made by 
the lower courts. The main sentiment of the Court reflected dissatisfaction with Albemarle's validation strategies based on requirements provided in the Uniform Guidelines, and the 1974 edition of the Standards. Writing the opinion for the majority, Justice Stewart cited four major issues. First, out of ten job classifications only three validity correlations were significant. Further, no evidence existed to support the generalizability of these correlations to the other job categories because none of them were job analyzed. Thus, there was no way of substantiating that the jobs categories used to validate the selection procedure and the new job categories were in fact similar. Second, the use of supervisory ratings in the validation study was rejected because the criteria for job performance considered could not be properly determined. Third, the progression of promotion from lower-level jobs to upper-level jobs was not recorded. Finally, the sample only included "job-experienced white workers" which further complicated the ability of results to be generalizable to new, young, and nonwhite applicants. Additionally, the Court determined that plaintiffs could demonstrate pretext by "showing that less discriminatory alternatives to the achievement of the employer's goal were available" (Gutman, 2005).

The traditional adverse impact rules established in Griggs and Albemarle were altered in decisions made in Watson v. Fort Worth Bank \& Trust (1988) and Wards Cove v. Antonio (1989). In Watson, evidence indicated that subjective supervisory ratings were the cause of adverse impact for the "total selection process" for employee promotions. However, the entire selection procedure included ratings obtained from interviews, job performance and past experience, thus obfuscating the direct cause of adverse impact. In a plurality opinion (i.e., an opinion resulting from a case where no majority was found), 
Justice O'Connor responded to this issue by altering the prima facie burden on the plaintiff by instating a requirement to identify the specific employment practice and present compelling proof of causality. Further, the burden of persuasion observed in the Griggs-Albemarle tradition was changed to a burden of production as in McDonnellBurdine. In other words, if the plaintiff was able to satisfy the identification and causation provisions in phase 1 , the defendant would only need to articulate a legitimate business explanation for the statistical disparity to satisfy the burden of proof in Phase 2. The demonstration of pretext in Phase 3 was untouched. The alteration to the adverse impact judicial scenario was held by a 5-4 majority opinion in Wards Cove, which involved cross-job disparities as a result of questionable hiring and recruitment strategies. In the Civil Rights Act of 1991 (CRA-91), Congress codified the identification and causation provisions in Phase1 but overturned the burden of production by reinstating the traditional burden of persuasion in Phase 2.

\section{EEOC Claims Process and Statistical Trends}

When an individual believes his or her employment rights have been violated, the first step is to contact a federal, state or local government employment agency such as the Equal Employment Opportunity Commission (EEOC). All laws enforced by the EEOC (except for the Equal Pay Act, EPA) require the charge be filed with the EEOC before private representation may be pursued (Landy, 2005). The individual or group of individuals filing claim is referred to as the charging party. Once the claim has been filed with the agency the investigation stage begins. At this stage, the agency contacts the employer to gather basic information regarding the alleged discriminatory practice. The gathered information is used by the EEOC to determine if the charging party has 
reasonable cause, or merit. If the agency determines the case has merit, they will attempt to negotiate an amicable solution for both parties though a process known as conciliation. If the agency and the employer cannot come to an agreement, the agency can choose to further represent the charging party in the formal adversarial arena or issue a right to sue notification allowing the party to request representation privately (Landy, 2005).

In order to file a formal lawsuit in federal court under Title VII provisions, a claim of discrimination by the charging party must be processed by a regulatory agency. The requirement was enacted to reduce the number of potential frivolous lawsuits; however, it does not always work that way. In fact, even if the EEOC finds the claim of discrimination to have no reasonable cause, the charging party will legally maintain the right to sue, but must seek representation elsewhere. Thus, any party who feels they were discriminated against can pursue litigation as long as they file with an agency first. There are three circumstances in which the right-to-sue notification will be issued: (1) it will be automatically issued if the agency finds the claim to have no reasonable cause, (2) the charging party may request it after 180 days pass, and (3) in the event the agency finds merit but is not able to resolve the charge with the employer in conciliation (Landy, 2005).

Statistical trends in EEOC discrimination claims. There are many sources of information available to gauge the nature of employment discrimination claims. For example, at the beginning of each year, the EEOC releases the previous year's charge statistics for discrimination charges filed under the EEOC four primary antidiscrimination laws: Title VII, the Americans with Disabilities Act (ADA), the Age Discrimination Act (ADEA), and the Equal Pay Act (EPA). Over the last 12 years, race 
and sex based discrimination charges have dominated claims filed under Title VII provisions. Of the 93,277 discrimination charges filed in 2009, 36\% were race-based and $30 \%(28,028)$ were sex-based (EEOC, 2009d). Table 2 illustrates the total number and percentage of charges filed with the EEOC for both race- and sex- based charges.

Table 2

Total Number and Percentage of Title VII EEOC Charges Filed in 2009 by Basis and Resolution Type

\begin{tabular}{lcc}
\hline & Race Based Charges & Sex Based Charges \\
\hline Receipts & 33,599 & 28,028 \\
Resolutions & 31,129 & 26,618 \\
Resolutions by Type & & \\
$\quad$ Administrative Closure & $4,803(15.4 \%)$ & $5,701(21.4 \%)$ \\
$\quad$ No Reasonable Cause & $20,530(66.0 \%)$ & $15,139(56.9 \%)$ \\
$\quad$ Merit Resolutions & $5,796(18.6 \%)$ & $5,778(21.7 \%)$ \\
Monetary Recovery (Millions) & $\$ 82.4$ & $\$ 121.5$
\end{tabular}

Note: Merit resolutions include negotiated settlements, withdrawals with benefits, successful conciliations and unsuccessful conciliations that have outcomes favorable to the charging party.

There are some interesting differences between the two charge bases to note.

First, a greater percentage of race-based charges $(66 \%)$ were found to have no reasonable cause than sex based charges (56.6\%). Second, though the number of merit resolutions resolved by the EEOC for each basis was similar (a difference of 18 cases), the monetary recovery for sex-based claims (\$121.5 million) was significantly higher than monetary recovery in race based cases ( $\$ 82.4$ million). These results have been consistently seen in the past 12 years; despite lower sex based charges, the basis consistently brings in more monetary benefits than race based charges (EEOC, 2009d). 
Research has also indicated that an organization's likelihood of winning a discrimination case depends on the type of alleged discrimination. For example, Terpstra and Kethley (2002) investigated the outcomes of actual federal court cases by discrimination type. Results confirmed EEOC statistics in that the majority of discrimination charges were based on race (50\%) and sex (28\%). However, a greater percentage of sex-based cases (66\%) were found to be favorable to the defendant than race-based cases (59\%). Overall, 65 percent of federal courts ruled in favor of the employer, while 35 percent ruled in favor of the plaintiff.

In addition, an organization's frequency of exposure to discrimination litigation can be influenced both by industry and job type (Terpstra \& Kethley, 2002). Of the 371 federal court cases involving selection devices identified, 133 (37\%) were associated with the public administration or government sector, 85 (24\%) were associated with the service industry, and $74(20 \%)$ were associated with the manufacturing industry. Further, service jobs were associated with $91(26 \%)$ of the total court cases. The job type was overrepresented based on the percentage of workers currently employed (17\%). Not surprising, the majority of cases (68) involved protective agencies (e.g., law enforcement, firefighters, etc.).

Another similar analysis of federal court cases involving discriminatory selection procedures assessed the impact of particular types of selection devices on the relative frequency of litigation (Terpstra et al., 1999). The researchers investigated nine "substantive" selection devices: unstructured interviews, structured interviews, biographical information banks, cognitive ability tests, personality tests, honesty (or integrity) tests, physical ability tests, work sample tests and assessment centers. Out of 
158 cases, 91 involved unstructured interviews, 28 involved cognitive ability tests, and 22 involved physical ability tests. In terms of outcomes, 59 percent of unstructured interviews, 67 percent of cognitive ability tests and 58 percent of physical ability tests were found in the favor of the employer. These three devices were also found to be overrepresented and, thus, associated with relatively greater legal risk. Both structured interviews and assessment centers discrimination charges were decided 100 percent of the time in favor of the defense.

The EEOC may be the filter through which all private sector claims are sorted, but the rules surrounding garnishment of right-to-sue letters seem to contradict the purpose of frivolous claiming activity. Any claiming party, regardless of the results of an EEOC investigation, will undoubtedly receive a right-to-sue letter allowing them to pursue private representation. What remains unanswered is how attorneys who receive these representation requests evaluate the characteristics of statements reported as well as of the rejected applicants who make such claims.

\section{I/O Science vs. Legal Practice: Ambiguities in the EEO Landscape}

After review of extant literature on the current state of the EEO landscape in regard to adverse impact (Gutman, 2000, 2005, 2009; Landy, 2005; Sharf, 1999; Sharf \& Jones, 2000) it is conclusive that large ambiguities remain in both the I/O professional and legal arenas. First, though the Uniform Guidelines have yet to be revised in over 30 years, they remain the most cited authority by the courts. Second, because the Supreme Court has not revisited its controversial decisions made in Watson or Wards Cove, the CRA-91 rules for adverse impact remain a large ambiguity. Third, it is unclear whether the aforementioned strategies for adverse impact (i.e., test score banding) will withstand 
legal scrutiny. Lastly, though it is clear to I/O professionals what types of validity

evidence are best in matters of adverse impact, the courts may not always agree.

Authoritative sources. Both the Standards and the Principles are deeply rooted in psychological measurement principles. The Standards preceded publication of both the Principles and the Uniform Guidelines, with the first publication in 1957. Since then the document has gone under four revisions. The purpose of the Standards "...is to promote the sound and ethical use of tests and to provide a basis for evaluating the quality of test practices" (p.1). The Principles were first established in 1975 in response to the need for professional standards in validation research, and since have undergone four revisions. The purpose of the Principles is not to interpret relevant case law but rather to provide a technical resource for users to consult (Jeanneret, 2005).

The Uniform Guidelines was authored by the Equal Employment Opportunity Commission (EEOC), the Department of Justice (DOJ), the Civil Service Commission (CSC), and the Department of Labor (DOL). Unlike the Standards and the Principles, the content of the Uniform Guidelines is more concerned with proper validity documentation than scientific and psychometric principles. Despite many professional disagreements regarding the presentation of several key technical issues (see Camera, 1996) the EEOC, the DOJ, and the Office of Federal Contact Compliance Programs (OFCCP) continue to rely on the Uniform Guidelines in matters of allegedly discriminatory selection procedures. Further, though undoubtedly the knowledge of psychometric principles has evolved over the past thirty years, the Uniform Guidelines have yet to be updated. The courts most frequently cite the Uniform Guidelines in matters regarding discriminatory selection procedures, though combined all three authoritative sources are cited rarely 
(Jeanneret, 2005). The situation thus suggests that the courts and federal agencies may lack appropriate knowledge in regard to psychological and psychometric principals critical to discriminatory selection procedures.

Rules for adverse impact. The CRA-91 achieved two critical goals. First, the burden of persuasion from the Griggs - Albemarle tradition was recovered. Second, by codifying the identification and causation provisions it is likely that weak intentional discrimination claims will not be regarded as adverse impact claims. In the case of inseparable total selection disparities, it remains unclear when and by what criteria the court will choose to shift the burden of identification to the defendant (Gutman, 2000).

Strategies for adverse impact reduction \& scoring procedures. Two common strategies for adverse impact reduction have met difficulty in the courts: (1) banding procedures and (2) cutoff scores. Though banding is not illegal per se, it is the professional opinion of some that adverse impact cannot be legally reduced though implementation of these psychometric solutions (Gutman, 2000). For example, the banding strategy proposed by Cascio, Outtz, Zedeck, and Goldstein (1991) did not survive judicial scrutiny in either Bridgeport Guardians v. City of Bridgeport (1991) or Officers for Justice v. Civil Service Commission (1992). The 2nd and 9th circuit courts rejected the strategy because it employed sliding bands and minority preferential selection within the bandwidth. The issue in this case was the fact that minority preference was the only basis for within-band selection (Gutman, 2000). In the case of sliding bands it may be more beneficial to use other criteria of adjustment or selection.

In Lanning v. Southeastern Pennsylvania Transportation Authority (SEPTA)

(1999) the third circuit in this case took the business necessity burden to mean "minimal 
qualifications necessary for successful job performance" (Gutman, 2005). This determination contradicts traditions demonstrated in Griggs and Wards Cove by suggesting a requirement to show all or most applicants below a predetermined cutoff score would not demonstrate effective job performance (Sharf, 1999). Prior to this decision the courts relied on the Uniform Guidelines to assess the validity of cutoff scores. This standard stated that when cut off scores were used "should be normally set so as to be reasonable and consistent with normal expectations of acceptable job performance within the work force." This difference of opinion may not only impact the use of cut off scores, but also affect the types of validity evidence accepted to meet the employer burden of persuasion.

Validity evidence. Though professionally speaking, criterion-related evidence is highly regarded, decisions made by the courts do not always follow this professional standard. As seen in Brunet v. City of Columbus (1995), content validity may in fact overshadow criterion-related evidence when properly established. In this case, a job analysis of a firefighting revealed both physical abilities and cognitive abilities as key KSAOs to be assessed in selection. The City of Columbus weighed the physical ability test as $70 \%$ and the cognitive ability test as $30 \%$, which resulted in adverse impact for females. There was however, competing evidence regarding which of these predictors was better suited to predict subsequent job performance. A criterion-related validity study revealed the cognitive ability test to be more predictive of job performance, whereas a content validity study revealed the physical ability test was better at distinguishing superior firefighters from average ones. The court sided with the defendants and held that the city's weighting was justified by the results of the content validity study (Gutman, 
2000). Thus, it is uncertain to what degree different types of validation evidence provide acceptable legal justification for adverse impact, and further, which will prove to be most advantageous in the advent of a discrimination suit (Gutman, 2000, 2005).

Clearly, there are many questions regarding discrimination that remain unanswered. As of yet, the impact of actual and perceived discrimination on subsequent attorney decision-making has not been addressed in empirical research. In regard to perceived discrimination, do applicant demographics and perceptions of job relatedness affect attorney determinations of organizational culpability thus, the desire to represent a potential client? Industrial/Organizational psychologists have continued to further the advancement of statistical procedures for reduction actual discrimination (adverse impact) in hopes of attaining heightened legal defensibility. However, without Supreme Court review of these issues the ability of any procedure to increase legal defensibility remains entirely uncertain. It is the view of the author that evaluation of these ambiguous issues by practicing attorneys may bring some resolution to these topics.

\section{PRESENT STUDY}

The present thesis sought to examine how attorneys make decisions in employment discrimination cases involving allegedly disparate personnel selection procedures. Specifically, the main purpose of the present study was to investigate how characteristics of a rejected applicant's statement affect an attorney's decision to represent the client. In addition, the investigation explored how various reported efforts to meet validation requirements by an organization will affect the attorney's (a) monetary compensation request for the potential client in settlement and (b) desire to pursue litigation. 
Using vignette methodology, attorneys read a statement from a rejected applicant seeking representation alleging that an organization used discriminatory personnel selection procedures. Three independent variables were manipulated in the scenarios. First, the rejected applicant's protected group category was manipulated as race (a minority applicant) or sex (a female applicant). Second, the rejected applicant's perception of the degree of procedure relatedness to the targeted job was manipulated as job related (test content is perceived as related to performance expectations of a competent employee) or job unrelated (test content is perceived as unrelated to performance expectations of a competent employee). Third, the results of the EEOC investigation was manipulated as merit found (a right-to-sue letter was issued because the EEOC found the claim to have merit but was unable to successfully conciliate) or merit unknown (the 180 day time limit is fast approaching and the EEOC has not yet provided a right-to-sue letter).

The main dependent variable of the present investigation was the attorney's likelihood of representing the rejected applicant; however, three other variables were included in hypothesis testing. Additional dependent variables included the attorney's (1) degree of confidence in obtaining favorable outcomes in the event the client was retained, (2) degree of applicant claim credibility, and (3) projected course of legal action.

Attorneys were also asked to indicate how various pieces of hypothetical evidence offered in discovery by the employer would affect their decisions regarding monetary compensation requests in settlement and likelihood of pursing litigation. These pieces of evidence represent efforts by test users and test professionals to meet validation requirements and reduce actual discrimination. Items for this portion of the questions 
represented: (1) the five criteria established in Guardians, (2) several ambiguities between professional practice, authoritative guidelines, statutory authority and legal precedent and (3) widely accepted strategies for reducing adverse impact (e.g., Ryan \& Tippins, 2004; Ployhart \& Holtz, 2008). Hypotheses regarding projected relationships between independent variables and dependent variables are discussed according to independent variable type (projected group category) and function (mitigating and aggravating factors) in the following sections.

\section{Protected Group Category}

Equal Employment Opportunity Commission (EEOC, 2009b; 2009c; 2009d) statistics demonstrate that the most frequent claims made under Title VII provisions are race- and sex-based claims. Though racial discrimination charges are claimed at a higher frequency than sex discrimination claims, they are also more likely to be found lacking merit. Additionally, sex discrimination cases tend to garner greater monetary compensation than racial discrimination cases. Thus it was hypothesized that:

Hypothesis 1(a). Attorneys would be more likely to represent a potential client if the claim involved a charge of sex discrimination than if the claim involved a charge of racial discrimination.

Hypothesis 1(b). Attorneys would be more likely to be confident in favorable outcomes if the potential client's claim involved a charge of sex discrimination than if the claim involved a charge of racial discrimination.

Hypothesis 1(c). Attorneys would perceive the potential client's claim to be more credible if the claim involved a charge of sex discrimination than if the claim involved a charge of racial discrimination. 
Hypothesis 1(d). Attorneys would indicate a higher degree of litigiousness (i.e., a more aggressive course of legal action) if the potential client's claim involved a charge of sex discrimination than if the claim involved a charge of racial discrimination.

\section{Aggravating and Mitigating Factors}

For attorneys, litigation and settlement negotiations involve a delicate evaluation of costs and benefits such as time and money invested by both the client and the attorney. To conceptually legitimize pursing any course of legal action, attorneys must have some confidence that the employer's actions were egregious enough to warrant successful outcomes for both themselves and their client. Present in every discrimination case are aggravating and mitigating factors to the organization's perceived culpability. In this investigation, aggravating factors will represent independent variable levels that increase organizational culpability (e.g., procedure content unrelated to the job, and a claim found to have merit by the EEOC). Conversely, mitigating factors represent independent variable levels that decrease organizational culpability (e.g., procedure content related to the job, and no knowledge of EEOC final determination).

In the applicant perceptions literature, it is widely accepted that selection procedures that appear to be related to the job are perceived to be fair by test takers (Smithers, et. al., 1993). Further, Thibodeaux and Kudisch (2003) found that when applicants perceived a testing procedure to be unrelated to job, they were more likely to complain. It is assumed here that this determination will resonate with the attorney such that procedures perceived to be job related will be less likely to be viewed as discriminatory, and thus unworthy of representation or further applicant supportive actions. Thus it was hypothesized that: 
Hypothesis 2(a). Attorneys would be more likely to represent a potential client if the selection procedure content was perceived to be unrelated to the targeted position than if content was perceived to be related.

Hypothesis 2(b). Attorneys would be more confident in favorable outcomes if the selection procedure content was perceived by the potential client to be unrelated to the targeted position than if content was perceived to be related.

Hypothesis 2(c). Attorneys would perceive the potential client's claim to be more credible if the selection procedure content was perceived by the potential client to be unrelated to the targeted position than if content was perceived to be related.

Hypothesis 2(d). Attorneys would indicate a higher degree of litigiousness if the selection procedure content was perceived by the potential client to be unrelated to the targeted position than if content was perceived to be related.

Hypothesis 3(a). Attorneys would be more likely to represent a potential client if the EEOC found the discrimination claim to have merit than if the results were unknown.

Hypothesis 3(b). Attorneys would be more confident in favorable outcomes if the EEOC found the discrimination claim to have merit than if the results were unknown.

Hypothesis 3(c). Attorneys would perceive the potential client's claim to be more credible if the EEOC found the discrimination claim to have merit than if the results were unknown.

Hypothesis 3(d). Attorneys would indicate a higher degree of litigiousness if the EEOC found the discrimination claim to have merit than if the results are unknown. 


\section{METHOD}

\section{Participants}

Participation request emails were sent to: (1) American Bar Association (ABA) registered employment \& labor law blog contributors $(n=150),(2)$ employment $\&$ labor law firms $(n=722)$, and (3) professional contacts $(n=26)$. One hundred and thirty four attorneys were included in the present study ( 31 women, 56 men, $M_{\text {age }}=41.6$, age range $=24-85)$, resulting in a response rate of $14.9 \%$. As a note, not all participating attorneys provided responses to demographic questions. The percentages reported here are derived from participants who provided responses to demographic questions and do not include those attorneys who choose not respond. The majority of attorneys were white nonHispanic (82.8\%) and Hispanic (13.8\%). Attorney location of practice ranged across 23 different North American states, with the majority being from Florida (14.8\%), Texas $(13.6 \%)$ and the District of Colombia (7.4\%). Average tenure of attorney practice was 15.11 years $(S D=11.39)$. In addition to requesting participation, the email also provided information about the study, a request to forward study to colleagues and a web-link to the survey created by and housed within Qualtrics online survey software (http://www.qualrics.com).

Criteria for participation required law school coursework in employment/labor law and/or practical experience in employment labor law. The majority of participants were practicing attorneys $(92.0 \%)$. The remaining participants were $3^{\text {rd }}$ year law students, law school graduates who had either passed the BAR exam and were awaiting employment or had not yet taken the BAR exam. The majority of attorneys reported practical experience in areas of employment/labor law (82.1\%), and civil rights law 
(33.3\%). Many attorneys (53.0\%) indicated they had "litigated an employment dispute regarding employment selection". Of these attorneys, $36.4 \%$ had represented the plaintiff (employee) and $63.6 \%$ had represented the defendant (employer). Further, a significant portion of attorneys indicated involvement in a Title VII dispute (71.1\%). Of these attorneys, $34.4 \%$ were plaintiff counsel and $65.6 \%$ were defendant counsel. The majority of these cases involved racial discrimination (62.0\%), followed by sex discrimination (33.8\%) and religious discrimination (4.2\%).

\section{Materials}

The attorney survey included a vignette and a questionnaire. The present study was 2 X 2 X 2 between-subjects design, and thus provided eight conditions. Eight individual vignettes were created to satisfy the eight conditions of the study (see Appendix A). Three independent variables were manipulated in the vignettes: rejected applicant protected group category (race or sex), rejected applicant perception of selection procedure job relatedness (job related or job unrelated), and the results of the EEOC investigation (merit found or merit unknown).

\section{Vignettes}

The vignettes presented four statements from a potential client seeking representation in an employment dispute over the legitimacy of a personnel selection test. The first statement described the potential client's qualifications, which included a B.A. in Accounting, licensure as a certified public accountant (CPA), and 10 years of relevant experience. The potential client also stated the reason for seeking the targeted position was because they decided to relocate. In the second statement the potential client stated they had applied to an accounting position, were asked by a hiring manager to take a 
battery of tests to determine if they were fit to be hired, and were subsequently rejected because they were a "mismatch" to what the organization was looking for. Both of these statements were consistent across all eight conditions.

The third statement described the (1) potential client's perception of how related the selection procedure content was to the targeted position, and (2) their suspicion that the scoring method may cause discrimination (disparate impact). For the purpose of the present study no evidence of organizational intent was explored. The first portion of the statement described the rejected applicant's perceptions of job relatedness including both a statement of face validity as well as a statement of perceived predictive ability (Smither et al., 1993). Job relatedness was manipulated as job related (e.g., "In terms of the content of the selection test, I felt the items were related to the level of performance expected of a competent accountant. It was clear that a person who did well on these tests would do well on the job.") or job unrelated (e.g., "In terms of the selection test I did not understand how the items were related to performance expectation of a competent accountant. Generally, the items seemed to be unrelated to the job. Further, it was unclear to me that a person who did well on these tests would do well on the job.").

Regardless of job relatedness condition the rejected applicant made a statement suggesting there may be possible disparate impact due to scoring procedures implemented by the hiring organization (e.g., "I suspect the method in which the items were scored may be detrimental to minority (female) applicants, perhaps because they do not account for the unique experiences of minorities (female)." Protected group category was manipulated as race (minority) or sex (female). 
In the fourth statement, the potential client described results of an investigation conducted by the EEOC. The results of the EEOC investigation were manipulated as merit found (e.g., "Though my charge was found to have merit after an initial investigation, the EEOC informed me they were unable to successfully conciliate with the employer.") or merit unknown (e.g., "The 180 day time limit is fast approaching and the EEOC has yet to inform me of the results of the investigation. I am planning on requesting a right-to-sue letter so I can seek private representation.”).

Job qualification pretest. In an effort to control for perceived differences in applicant qualification on likelihood of representation, two job qualifications descriptions were generated to represent two different job types: accountant and architect. The descriptions were written to reflect an applicant who has sufficient qualification to be hired by the target organization for the targeted position. Job information for both the accountant description (http://online.onetcenter.org/link/summary/13-2011.01) and for the architect description (http://online.onetcenter.org/link/summary/17-3011.01) were obtained from $\mathrm{O} *$ Net Online. Additional information regarding architect licensing requirements were obtained from the Florida Chapter the American Institute of Architects (AIA): Career Resources - Quick Facts (http://www.aiafla.org/Career-Resources_QuickFacts.cfm) and included in the architect description.

Both rejected applicants in these scenarios had graduated from a top-tier university, completed requisite milestones (e.g., the accountant received their CPA and the architect completed an internship), and had 10 years of job experience. Both applicants cite spousal relocation as the reason for the current job application. 
A sample of $18 \mathrm{I} / \mathrm{O}$ psychology graduate student subject matter experts (SMEs) were randomly assigned to assess either the accountant or architect qualifications. Subject matter experts were asked to indicate how qualified they perceived the applicant to be based on the information provided in the job qualification description on a 5-point Likert scale where $1=$ not at all, $2=$ slightly, $3=$ moderately, $4=$ quite $a$ bit , and $5=$ extremely. An independent samples t-test was conducted to compare the qualification scores for accountant and architect applicants. There was no significant difference in scores for architects $(M=4.11, S D=.60)$ and accountants $(M=4.22, S D=.44), t(18)=-.45, p=$ .66 (two-tailed). The magnitude of the difference in the means (mean difference $=-.11$, $95 \%$ CI: -.64 to .42 ) was very small (eta squared $=.007$ ). Because the differences were minimal, the accountant description was chose for use in the vignettes as it had a slightly greater mean for qualification scores and slightly less variability in qualification scores.

\section{Questionnaire}

After reading the vignette, attorneys were directed to complete a questionnaire that assessed how the independent variables influenced attorney likelihood of representing the potential client, degree of confidence in favorable claimant outcomes, degree of rejected applicant claim credibility, and attorney course of legal action. Additionally, attorneys were asked to indicate how several hypothetical pieces of evidence would affect their monetary compensation request for the potential client in settlement and desire to pursue litigation.

Attorneys were asked to indicate likelihood of representation (e.g., "Using the information provided by the potential client please indicate the likelihood that you would choose to retain this client for representation") on a 5-point Likert scale where $1=$ not at 
all likely, $2=$ slightly likely, $3=$ moderately likely, $4=$ quite a bit likely, and $5=$ extremely likely. The attorney's confidence in a favorable outcome (e.g., "If you chose to represent this client, how confident would you be that the outcome would be in your favor?") and evaluation of claim credibility were both provided on a 5-point Likert scale where $1=$ not at all, $2=$ slightly, $3=$ moderate, $4=$ quite $a$ bit , and $5=$ extremely. To measure the effect of the independent variables on attorney course of legal action, the attorneys were asked to choose the action they would most likely pursue (e.g., "Recommend the applicant dismiss the case "; "Contact the organization for further information about the selection procedure used"; "Immediately file the case").

Lastly, attorneys indicated how several efforts in selection procedure compliance (e.g., job analysis, validity, validity generalization, cut off scores, and test construction) would affect their (a) monetary compensation request in settlement (e.g., "Please indicate how each of the following pieces of evidence would impact your initial monetary compensation request in a settlement negotiation with the organization") and (b) desire to pursue litigation. (e.g., Please indicate how each of the following pieces of evidence would impact your desire to pursue litigation"). Both determinations were indicated on a 5-point Likert scale where 1 = significantly decrease, 2 = moderately decrease, $3=$ neither increase nor decrease, $4=$ moderately increase, and $5=$ significantly increase. Typically, counsel for both the employee and employer will attempt to settle the matter out of court, rather than hastily entering the adversarial process. In the event that evidence gathered by an employee attorney indicates organizational wrongdoing, it can be used to barter for larger compensation sums in settlement. Further, evidence that indicates an organizational transgression will ultimately define whether litigation is 
necessary or warranted. Thus, it is important to understand how reported organizational efforts may increase or decrease both the amount of monetary compensation requested to settle the dispute in and out of the adversarial setting.

After completing the dependent measures questionnaire, attorneys were directed to complete standard demographic questions (e.g., their sex, age, race) as well as more study specific questions. Specifically, attorneys were asked what year they obtained their law degree, how long they have been practicing law, and what type of law they practice. Attorneys were also asked if they had been involved in an employment discrimination suit involving a selection procedure professionally and, if so, what party they represented (e.g., the defendant/employer or the plaintiff/employee). Further, attorneys were asked if they have personally been involved in an employment discrimination suit and, if they had, what role they assumed (e.g., witness, expert, plaintiff, defendant, plaintiff's counsel, defendant's counsel).

\section{Procedure}

After clicking the link provided in the recruitment email, attorneys were brought to the Qualtircs online survey software site (http://www.qualtrics.com). Attorneys read and submitted consent to participate and were then randomly assigned to condition by a randomizing function within the survey software. This function presented one of the eight unique vignettes to each attorney. After reading the vignette, attorneys answered the questionnaire and completed the demographic sheet. 


\section{RESULTS}

\section{Manipulation Checks}

In order to analyze the effectiveness of manipulations, attorneys were asked three true or false knowledge questions related to the independent variables (e.g., "The EEOC will provide a right-to-sue letter to a claiming party whenever one is requested.") and two questions regarding specific information presented in the vignette (e.g., "What type of job was the rejected applicant applying for?"). Responses to these 5 items were combined into a scale score with a potential range of 0 to 5 , with 5 being the highest possible score. Of the 105 attorneys who answered the manipulation check questions, $33.6 \%$ received a total score of 5, 39.8\% received a total score of $4,17.2 \%$ received a score of 3 and only $5.2 \%$ received a score less than 3 .

A series of independent groups t-tests were conducted to compare the manipulation check scores for attorneys who received a score of 5 to attorneys who received a score of 4 or less across the four dependent variables. There was no significant difference in representation outcomes for attorneys who received a score of $5(M=2.39$, $S D=.92)$ and those that received a score of 4 or less $[M=2.15, S D=1.00 ; t(110)=$ $1.27, p=.21]$. There was no significant difference for confidence in favorable outcomes between attorneys who received a score of $5(M=2.18, S D=.90)$ and those that received a score of 4 or less $[M=2.20, S D=.86 ; t(110)=-.11, p=.92]$. There was also no significant difference in perceived claim credibility for attorneys who received a score of $5(M=2.63, S D=.79)$ and those that received a score of 4 or less $[M=2.08, S D=.28 ; t$ $(111)=.10, p=.92]$. There was, however, a significant difference in course of legal action for attorneys who received a score of $5(M=2.9, S D=.55)$ and those that received 
a score of 4 or less $[M=2.73, S D=1.02 ; t(107.40)=2.91, p<.01]$. The magnitude of the differences in means (mean difference $=.44,95 \% \mathrm{CI}: .14$ to .73 ) was moderate (eta squared $=0.07)$. Considering the majority of attorneys scored a 5 or 4 on the manipulation check, an additional t-test was conducted with less stringent grouping of scores to investigate the significant mean difference across manipulation check scores further. With such grouping, there was no significant difference in course of legal action found for attorneys who received a score of 5 or $4(M=2.90, S D=.83)$ and those that received a score of 3 or less $[M=2.79, S D=1.11 ; t(39.71)=.48, p=.64)$.

In addition, an independent groups t-test was conducted to determine if differences in manipulation check scores were a function of employment/labor law practical experience. No significant difference in scores was found between attorneys with employment/labor practical experience $(M=3.90, S D=.93)$ and those who had only taken an employment/labor course in law school $[M=4.28, S D=1.14 ; t(70)=-1.34, p=$ $.18]$.

Attorney knowledge assessment. In light of the significant difference found between attorneys who scored 5 and those who scored 4 or less on the manipulation checks for course of legal action, further analyses were conducted using an attorney knowledge assessment. In addition to standing on dependent variables, this assessment was also used to consider the differences in those attorneys who had practiced employment/labor law and those who had taken an employment course in law school but had no practical employment/labor law experience.

To assess attorney knowledge a 6-item measure was developed based on employment test quality and standards precedent set in Guardians of New York v. Civil 
Service Commission (1980). The attorney knowledge measure was included in the exploratory portion of questionnaire where attorneys read hypothetical pieces of evidence presented by an organization accused of discriminatory selection procedures. Attorneys indicated how this information would impact both their initial monetary compensation and desire to pursue litigation on a 5-point Likert scale where 1= greatly decrease and 5 $=$ greatly increase .

For the purposes of this study, the 5-points of the Guardians test were reorganized into three distinct categories: (1) test standards, (2) scoring procedures, and (3) validation efforts. An item with a high-level (e.g., high test standards; "Evidence that (1) a suitable job analysis was conducted recently and (2) a competent and reputable professional was used to construct the tests") and a low-level (e.g., low test standards; "Evidence that (1) the target position's job analysis was conducted 5 years ago and (2) that the selection test was purchased from an outside distributor") were created for each of the three categories. Thus resulting in a total of 6 items to assess attorney knowledge (see p. 18 for more information on the Guardians 5-point test). It was assumed that if the attorney had requisite knowledge of the requirements for legally sound test standards and procedures, high-level items would result in lower monetary compensation requests and desire to pursue litigation and low-level items would result in higher monetary compensation requests and desire to pursue litigation. Following this logic, high-level items were reverse coded to translate low scores into high standing on attorney knowledge. Finally, responses to the 6 items were combined into a scaled score with a potential range of 0 to 30 for both decision outcomes. Though 30 was the highest possible score, scores of 30 were not expected as items were not extremely polarizing. Instead, ratings of 4 to 5 on 
low-level items and 3 to 5 on high-level items were deemed to demonstrate adequate knowledge which accommodating possible differences in outcomes aggressiveness. Thus, scores of 21 and higher $[(4 \times 3)+(3 \times 3)]$ were determined to demonstrate an acceptable level of employment/labor law knowledge in regard to selection procedures. In general, average scores for both compensation $(M=23.31, S D=3.54)$ and litigation $(M=24.24$, $S D=3.08$ ) outcomes were above the determined cutoff score. Further, attorney knowledge for both decision outcomes were highly correlated $(r=.72, n=87, p<.001)$.

Two independent groups t-tests were conducted to investigate if attorney knowledge scores differed as a function of manipulation check scores. There was no significant difference in attorney knowledge for the compensation outcome between attorneys who scored $5(M=23.51, S D=3.48)$ and attorneys who scored 4 or below $(M$ $=23.21, S D=3.63 ; t(82)=.368, p=.71)$ on manipulation checks. Similarly, there was no significant difference in attorney knowledge between for the litigation outcome attorneys who scored $5(M=24.39, S D=3.33)$ and attorneys who scored 4 or below ( $M$ $=24.30, S D=2.89 ; t(82)=.13, p=.90)$.

Two additional independent groups t-tests were conducted to determine if differences in attorney knowledge scores were a function of employment/labor law practical experience. There were no significant differences in attorney knowledge scores for the compensation outcome between attorneys with employment/labor practical experience $(M=23.71, S D=3.53)$ and those who had only taken an employment/labor course $[M=21.84, S D=3.78 ; t(70)=1.70, p=.09]$. Similarly for the litigation decision outcome, no significant differences in attorney knowledge scores were found between 
attorneys with employment/labor practical experience $(M=3.90, S D=.93)$ and those who had only taken an employment/labor course $[M=4.28, S D=1.14 ; t(70)=-1.34, p=.18]$.

Dependent variable intercorrelations. Finally, manipulation checks investigated intercorrelations among the four dependent variables. Table 3 displays a summary of dependent variable intercorrelations. All dependent variables were intercorrelated at an alpha level of .001. These relationships indicate the experimental stimuli presented in the vignettes were effective. Further, relationships between dependent variables were not moderated by attorney practice tenure, thus extent of attorney practical experience did not have an effect on dependent variable outcomes.

Table 3

Summary of Dependent Variable Intercorrelations

\begin{tabular}{lcccccc}
\hline Dependent Variable & $M$ & $S D$ & 1 & 2 & 3 & 4 \\
\hline $\begin{array}{lcccc}\text { 1. Representation } \\
\text { 2. Confidence }\end{array}$ & 2.21 & 1.01 & - & & \\
$\begin{array}{l}\text { 3. Credibility } \\
\text { 4. Course of legal }\end{array}$ & 2.14 & .91 & $.62^{*}$ & - & \\
\begin{tabular}{l} 
action \\
\hline
\end{tabular}
\end{tabular}

Note. Representation $\mathrm{n}=133$, Confidence $\mathrm{n}=133$, Credibility $\mathrm{n}=134$, Course of legal action $\mathrm{n}=129$. All variables were rated using a 5 -point Likert scale. $* p<.001$.

\section{Hypothesis Testing}

A series of 2 X 2 X 2 ANOVAs (Protected Group x Job Relatedness x EEOC Decision) were run to test hypotheses: (1) four ANOVAs to test dependent variables and (2) three additional ANOVAs looking at the effects of independent variables on combined dependent variables. The following sections will consider the results of each 
ANOVA individually, and will be categorized according to the respective dependent variable considered in testing. For main effects, $d$ was calculated to investigate mean differences among levels of independent variables, when $d>.20$, the null hypothesis was rejected.

Representation. Attorneys were asked, "Please indicate the likelihood that you would choose to retain this potential client for representation" using a 5-point Likert scale where $1=$ not at all likely and $5=$ extremely likely. Table 4 displays cell means for representation decisions. A three-way analysis of variance was conducted to explore the impact of protected group category, job relatedness and EEOC decision on likelihood of representation. It was hypothesized that attorneys would be more likely to represent a rejected applicant if the claim involved a charge of sex discrimination (H1a), if the selection procedure was perceived to be unrelated to the targeted position (H2a) and if the EEOC had found the rejected applicants claim to be meritorious (H3a). Table 4 displays cell means for representation decisions.

Table 4

Analysis of Variance Cell Means: Representation

\begin{tabular}{lcccccccccccccc}
\hline & \multicolumn{4}{c}{ Merit Found } & \multicolumn{4}{c}{ Merit Unknown } \\
\cline { 2 - 14 } & \multicolumn{3}{c}{ Job Related } & \multicolumn{3}{c}{ Job Unrelated } & \multicolumn{3}{c}{ Job Related } & \multicolumn{3}{c}{ Job Unrelated } \\
\hline Minority & 16 & 2.13 & 1.03 & 15 & 2.80 & 1.08 & 17 & 2.18 & 1.02 & 17 & 1.88 & .78 \\
Female & 17 & 2.29 & 1.12 & 17 & 2.76 & .90 & 16 & 1.75 & .93 & 18 & 1.94 & .80 \\
\hline
\end{tabular}

Note. $\mathrm{N}=133$ 
The higher-order interaction effect between protected group, job relatedness and EEOC decision was not statistically significant, $F(1,125)=1.06, p=.30$. Simple interaction effects among independent variables were not statistically significant. The main effect for protected group $F(1,125)=.118, d=.06$, was not significant, thus, H1a was not supported. The main effects for job relatedness, $F(1,125)=2.42, d=.27$, and EEOC decision, $F(1,125)=11.02, d=.58$, were significant, thus H2a and H3a were supported. Post-hoc significance tests were conducted to investigate significant main effects. Two independent group $t$-tests were conducted to investigate mean differences between groups for both job relatedness and EEOC decision. Findings revealed the mean representation score for the job unrelated group $(M=2.33, S D=.98)$ were not significantly different than the job related group $(M=2.09, S D=1.03), t(131)=1.36, p$ $=.18$ (two-tailed). Though not significant, mean score differences demonstrate that an attorney is more likely to represent a client if the claim involved allegations that the selection procedure was unrelated to the job, rather then when procedures were perceived to be related to the job. Further, the mean representation score for the merit found group $(M=2.50, S D=1.06)$ was significantly different than the merit unknown group, $M=$ $1.94, S D=.88, t(124.31)=3.25, p<.001$ (two-tailed). These results suggest that an attorney is more likely to represent a client when the EEOC has found their claim of discrimination to be meritorious then when the merit determination is unknown.

Confidence. Attorneys were asked, "In the event that you choose to represent the rejected applicant, how confident would you be in a favorable outcome?" using a 5-point Likert scale where $1=$ not at all likely and $5=$ extremely likely. A three-way analysis of variance was conducted to explore the impact of protected group category, job 
relatedness and EEOC decision on confidence in favorable outcomes. It was hypothesized that attorneys would be more likely to be confident in favorable client outcomes if the claim involved a charge of sex discrimination (H1b), if the selection procedure was perceived to be unrelated to the targeted position $(\mathrm{H} 2 \mathrm{~b})$ and if the EEOC had found the rejected applicants claim to be meritorious (H3b). Table 5 displays cell means for confidence ratings.

Table 5

Analysis of Variance Cell Means: Confidence

\begin{tabular}{lccccccccccccc}
\hline & \multicolumn{4}{c}{ Merit Found } & \multicolumn{5}{c}{ Merit Unknown } \\
\cline { 2 - 14 } & \multicolumn{3}{c}{ Job Related } & \multicolumn{2}{c}{ Job Unrelated } & \multicolumn{2}{c}{ Job Related } & \multicolumn{2}{c}{ Job Unrelated } \\
\hline & $n$ & $M$ & $S D$ & $n$ & $M$ & $S D$ & $n$ & $M$ & $S D$ & $n$ & $M$ & $S D$ \\
\hline Minority & 16 & 2.13 & .89 & 16 & 2.50 & .89 & 17 & 1.82 & .81 & 16 & 2.06 & .85 \\
Female & 17 & 2.35 & 1.12 & 17 & 2.47 & .80 & 16 & 1.94 & 1.00 & 18 & 1.83 & .79 \\
\hline
\end{tabular}

Note. $\mathrm{N}=133$

The higher-order interaction effect between protected group, job relatedness and EEOC decision was not statistically significant, $F(1,125)=0.19, p=.89$. Simple interaction effects among independent variables were not statistically significant. The main effects for protected group, $F(1,125)=.018, d=.02$, and job relatedness, $F(1$, $125)=1.01, d=.17$, did not reach statistical significance. Thus, H1b and H2b were not supported. H3b, however, was supported, $F(1,125)=8.27, d=.58$. Post-hoc significance tests were conducted to investigate the significant main effect. An independent groups t-test revealed the mean confidence score for the merit found group $(M=2.36, S D=.92)$ was significantly different than the merit unknown group, $M=1.91$, 
$S D=.85, t(131)=2.95, p<.005$ (two-tailed). These results suggest that an attorney is more likely to have confidence in favorable client outcomes when the EEOC has found their claim of discrimination to be meritorious then when the merit determination is unknown.

Credibility. Attorneys were asked, "In your opinion, how credible was the applicant's claim?" using a 5-point Likert scale where $1=$ not at all likely and $5=$ extremely likely. A three-way analysis of variance was conducted to explore the impact of protected group category, job relatedness and EEOC decision on confidence in favorable outcomes. It was hypothesized that attorneys would be more likely to find a rejected applicant's claim credible if the claim involved a charge of sex discrimination (H1c), if the selection procedure was perceived to be unrelated to the targeted position $(\mathrm{H} 2 \mathrm{c})$ and if the EEOC had found the rejected applicants claim to be meritorious (H3c). Table 6 displays cell means for claim credibility ratings.

Table 6

Analysis of Variance Cell Means: Credibility

\begin{tabular}{|c|c|c|c|c|c|c|c|c|c|c|c|c|}
\hline & \multicolumn{6}{|c|}{ Merit Found } & \multicolumn{6}{|c|}{ Merit Unknown } \\
\hline & \multicolumn{3}{|c|}{ Job Related } & \multicolumn{3}{|c|}{ Job Unrelated } & \multicolumn{3}{|c|}{ Job Related } & \multicolumn{3}{|c|}{ Job Unrelated } \\
\hline & $n$ & $M$ & $S D$ & $n$ & $M$ & $S D$ & $n$ & $M$ & $S D$ & $n$ & $M$ & $S D$ \\
\hline Minority & 16 & 2.63 & .96 & 16 & 2.94 & .85 & 17 & 2.47 & .87 & 17 & 2.82 & 1.07 \\
\hline Female & 17 & 2.35 & .93 & 17 & 2.65 & .86 & 16 & 2.13 & 1.03 & 18 & 2.72 & .83 \\
\hline
\end{tabular}

Note. $\mathrm{N}=134$

The higher-order interaction effect between protected group, job relatedness and EEOC decision was not statistically significant, $F(1,126)=.17, p=.68$. Simple 
interaction effects among independent variables also did not reach statistical significance. The main effect for EEOC decision, $F(1,126)=.43, d=.11$, was not statistically significant, thus, $\mathrm{H} 3 \mathrm{c}$ was not supported. The main effects of protected group, $F(1,126)$ $=2.47, d=.27$ and job relatedness $F(1,126)=5.88, d=.42$, were found to be statically significant. Post-hoc significance tests were conducted to investigate significant main effects. Two independent group $t$-tests were conducted to investigate mean differences between groups for both protected group and job relatedness.

Though differences in protected group category were not statistically significant, $t$ $(132)=1.50, p=.14$, findings demonstrated that racial minority applicants $(M=2.71, S D$ $=.94)$ were viewed to be more credible than female applicants $(M=2.47, S D=.94)$. These differences in credibility scores was opposite of what was originally hypothesized in H1c. Further, the mean credibility score for the job unrelated group $(M=2.78, S D=$ .90 ) was significantly different than the job related group, $M=2.39, S D=.94, t(132)=$ $2.43, p<.05$ (two-tailed), thus $\mathrm{H} 2 \mathrm{c}$ was supported. Generally, these results suggest that rejected racial minority applicants who perceived the selection procedure to be unrelated to the targeted position were more likely to be viewed as credible than rejected applicants who viewed the selection procedure to be related to the targeted position.

Course of legal action. Attorneys were asked, "Please select which of the following courses of action you would be most likely to pursue given the information presented by the rejected applicant." Three possible courses of action were provided: (1) recommend the applicant dismiss the case, (2) contact the organization for further information about the selection procedure and (3) immediately file the case. Each option was coded in a manner that reflected its respective degree of claimant support and overall 
attorney litigiousness. The individual actions were coded as a 5-point scale according to this conceptualization to allow for more accurate comparisons across dependent variables: $1=$ recommend the applicant dismiss the case, $3=$ contact the organization for further information about the selection procedure, and $5=$ immediately file the case. Actual frequencies of course of legal action per condition are displayed in Table 7. Table 7

Frequency Distribution for Course of Legal Action Outcomes by Condition

\begin{tabular}{lccccccccc}
\hline & \multicolumn{3}{c}{ Merit Found } & \multicolumn{3}{c}{ Merit Unknown } \\
\cline { 2 - 9 } & \multicolumn{2}{c}{ Job Related } & \multicolumn{2}{c}{ Job Unrelated } & \multicolumn{2}{c}{ Job Related } & \multicolumn{2}{c}{ Job Unrelated } \\
\cline { 2 - 9 } & MIN & F & MIN & F & MIN & F & MIN & F \\
\hline $\begin{array}{l}\text { Course of } \\
\text { Action }\end{array}$ & $\%(n)$ & $\%(n)$ & $\%(n)$ & $\%(n)$ & $\%(n)$ & $\%(n)$ & $\%(n)$ & $\%(n)$ \\
\hline $\begin{array}{l}\text { Recommend } \\
\text { case dismissal }\end{array}$ & $25(4)$ & $25(4)$ & $0(0)$ & $6(1)$ & $6(1)$ & $25(4)$ & $25(4)$ & $11(2)$ \\
$\begin{array}{l}\text { Contact the } \\
\text { organization }\end{array}$ & $63(10)$ & $75(12)$ & $87(13)$ & $63(10)$ & $88(14)$ & $63(10)$ & $75(12)$ & $83(15)$ \\
$\begin{array}{l}\text { File the case } \\
\text { immediately }\end{array}$ & $12(2)$ & $0(0)$ & $13(2)$ & $31(5)$ & $6(1)$ & $12(2)$ & $0(0)$ & $6(1)$ \\
\hline
\end{tabular}

Note. MIN = Minority, $\mathrm{F}=$ Female.

A three-way analysis of variance was conducted to explore the impact of protected group category, job relatedness and EEOC decision on course of legal action outcomes. It was hypothesized that attorneys would be more likely to choose a more claimant supportive or litigious course of legal action if the claim involved a charge of sex discrimination (H1d), if the selection procedure was perceived to be unrelated to the targeted position (H2d) and if the EEOC had found the rejected applicants claim to be meritorious (H3d). Table 8 displays cell means for course of legal action outcomes. 
Table 8

Analysis of Variance Cell Means: Course of Legal Action

\begin{tabular}{lccccccccccccc}
\hline & \multicolumn{4}{c}{ Merit Found } & \multicolumn{5}{c}{ Merit Unknown } \\
\cline { 2 - 13 } & \multicolumn{3}{c}{ Job Related } & \multicolumn{2}{c}{ Job Unrelated } & \multicolumn{3}{c}{ Job Related } & \multicolumn{2}{c}{ Job Unrelated } \\
\hline & $n$ & $M$ & $S D$ & $n$ & $M$ & $S D$ & $n$ & $M$ & $S D$ & $n$ & $M$ & $S D$ \\
\hline Minority & 16 & 2.75 & 1.24 & 15 & 3.27 & .70 & 16 & 3.00 & .73 & 16 & 2.50 & .89 \\
Female & 16 & 2.50 & .89 & 16 & 3.50 & 1.15 & 16 & 2.75 & 1.24 & 18 & 2.89 & .83 \\
\hline
\end{tabular}

Note. $\mathrm{N}=129$. Course of legal action was rated using a 3-point scale, later converted to a 5-point scale for use in analyses.

The higher-order interaction effect (Protected Group X Job Relatedness X EEOC Decision) was not statistically significant, $F(1,121)=.17, p=.68$. Simple interaction effects of Protected Group X EEOC Decision, $F(1,121)=.05, p=.82$, and Protected Group X Job Relatedness, $F(1,121)=.05, p=.82$, were not statistically significant. However, the simple interaction effect between job relatedness and EEOC decision was found to be significant, $F(1,121)=7.35, p<.01$, partial eta squared $=.6$, suggesting the effect of perceptions of job relatedness on course of legal action are dependent upon EEOC decision. The interaction was disordinal (see Figure 1), making interpretation of main effects misleading (e.g., Cohen, 2002; Howell, 2002). Thus, follow-up tests focused solely on simple main effects because main effects could not be considered independently. A descriptive summary of both EEOC decision and job relatedness simple main effects are displayed in Table 9 and Table 10, respectively. 
Figure 1

Course of Legal Action: Job Relatedness X EEOC Decision Interaction Plot

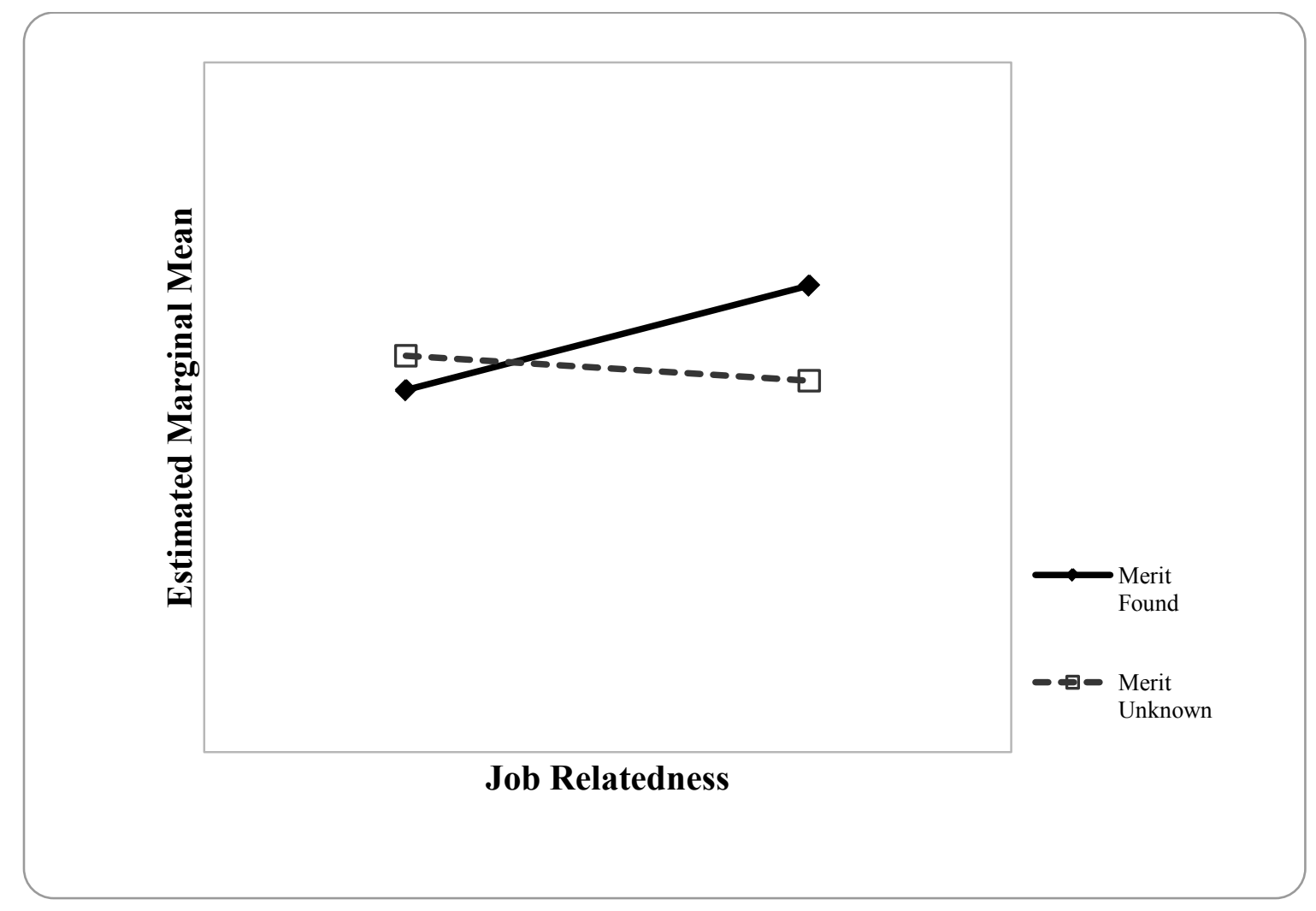

Note. Disordinal interaction.

Table 9

Descriptive Summary of EEOC Decision Simple Main Effects: Course of Legal Action

\begin{tabular}{lccccccccc}
\hline & \multicolumn{3}{c}{ Job Related } & \multicolumn{5}{c}{ Job Unrelated } \\
\cline { 2 - 9 } & $n$ & $M$ & $S D$ & CI & $N$ & $M$ & $S D$ & CI \\
\hline Merit Found & 32 & 2.63 & 1.07 & $\begin{array}{c}(2.24, \\
3.01)\end{array}$ & 31 & $3.39^{\text {a }}$ & .95 & $(3.04$, \\
Merit Unknown & 32 & 2.87 & 1.01 & $\begin{array}{c}(2.51, \\
3.23)\end{array}$ & 34 & $2.70^{\text {a }}$ & .87 & $(2.40$, \\
& & & & & & & $3.00)$ \\
\hline
\end{tabular}

Note. $\mathrm{CI}=95 \%$ confidence interval. $\mathrm{a}=$ significant simple main effect. 
A one-way analysis of variance was conducted to test the statistical significance of EEOC decision simple main effects, that is, the effect of EEOC decision on course of legal action outcomes at each level of job relatedness (job related v. job unrelated). To control for Type 1 error rates across the two simple main effects, the alpha level for each was set at $0.025(\alpha / 2=.05 / 2)$. A significant difference between EEOC decision conditions was found at the job unrelated level of job relatedness. A review of the group means indicated that in the job unrelated condition, more claimant supportive course of legal action outcomes were selected when the EEOC had found the claim to have merit $(M=3.39, S D=.95)$ than when the EEOC decision was unknown $(M=2.71, S D=.87)$, $F(1,64)=9.05, p<.005$. The calculated effect size was large $($ eta squared $=.12)$, indicating that actual differences in mean scores between groups was substantial. Table 10

Descriptive Summary of Job Relatedness Simple Main Effects: Course of Legal Action

\begin{tabular}{lccccccccc}
\hline & \multicolumn{3}{c}{ Merit Found } & \multicolumn{3}{c}{ Merit Unknown } \\
\cline { 2 - 9 } & $n$ & $M$ & $S D$ & CI & $N$ & $M$ & $S D$ & CI \\
\hline Job Related & 32 & $2.63^{\mathrm{a}}$ & 1.07 & $\begin{array}{c}(2.24, \\
3.01)\end{array}$ & 32 & 2.87 & 1.01 & $(2.51$, \\
& & & & & & & $3.23)$ \\
Job Unrelated & 31 & $3.39^{\mathrm{a}}$ & .95 & $\begin{array}{c}(3.04, \\
3.74)\end{array}$ & 34 & 2.70 & .87 & $(2.40$, \\
& & & & & & & $3.00)$ \\
\hline
\end{tabular}

Note. $\mathrm{CI}=95 \%$ confidence interval. a $=$ significant simple main effect.

An additional one-way analysis of variance was conducted to test the statistical significance of job relatedness simple main effects, that is, the effects of applicant perceptions of job relatedness on course of legal action outcomes at each level of EEOC decision (merit found v. merit unknown). To control for Type 1 error rates across the two 
simple main effects, the alpha level for each was set at $0.025(\alpha / 2=.05 / 2)$. A significant difference between job relatedness conditions was found in the merit found level of EEOC decision. A review of the group means indicated that in the merit found condition, more claimant supportive course of legal action outcomes were selected when the applicant had perceived the selection procedure to be unrelated to the target job $(M=$ $3.39, S D=.95)$ than when the applicant perceived the selection procedure to be related to the target job $(M=2.62, S D=1.07), F(1,62)=8.88, p<.005$.

Combined dependent variables. Conceptually, the four dependent variables could be aggregated pair-wise into two distinct categories: (1) an aggregate of attorney perception of the rejected applicant and (2) an aggregate of likely action outcomes. Thus, dependent variables of representation and course of legal action were combined to represent an overarching depiction of the attorney's decision-making processes regarding likely outcomes for the rejected applicant and their claim. Further, dependent variables of attorney confidence in favorable outcomes and perceptions of rejected applicant claim credibility were combined to provide a holistic analysis of attorney perceptions of the applicant. Thus, two additional 2 X 2 X 2 ANOVA's were run to allow comparison of combined dependent variables across independent variables. Each of the new combined dependent variable scores could range from 1 to 10 , as all previous variables were rated on 5-point scales.

Perceptions of the rejected applicant aggregate (confidence + credibility). A three-way analysis of variance was conducted to explore the impact of protected group category, job relatedness and EEOC decision on perceptions of the rejected applicant. Table 11 displays cell means for the rejected applicant aggregate. 
The higher-order interaction effect between protected group, job relatedness and EEOC decision was not statistically significant, $F(1,125)=.02, p=.87$. Simple interaction effects among independent variables also did not reach statistical significance. Additionally, the main effect for protected group, $F(1,125)=.68, d=.14$, did not reach statistical significance. However, the main effect for job relatedness $F(1,125)=3.82, d$ $=.34$ and EEOC decision $F(1,125)=3.40, d=.32$ were statistically significant. Follow up independent group $t$-tests were conducted to investigate mean differences between groups for both protected group and job relatedness.

Table 11

Analysis of Variance Cell Means: Perceptions of Rejected Applicant Aggregate

\begin{tabular}{ccccccccccccccc}
\hline & \multicolumn{4}{c}{ Merit Found } & \multicolumn{4}{c}{ Merit Unknown } \\
\cline { 2 - 15 } & \multicolumn{3}{c}{ Job Related } & \multicolumn{3}{c}{ Job Unrelated } & \multicolumn{3}{c}{ Job Related } & \multicolumn{3}{c}{ Job Unrelated } \\
\hline Minority & 16 & 4.75 & 1.29 & 17 & 5.44 & 1.63 & 17 & 4.29 & 1.79 & 16 & 4.88 & 1.82 \\
Female & 17 & 4.71 & 1.79 & 17 & 5.12 & 1.45 & 16 & 4.06 & 1.91 & 18 & 4.55 & 1.34 \\
\hline
\end{tabular}

Note. $\mathrm{N}=133$. Perceptions of Rejected Applicant is an aggregate of Confidence and Credibility dependent variables, resulting in a 10-point scale, with higher scores representing more favorable perceptions.

Though not significant, findings for job relatedness revealed the mean action outcome scores for the job unrelated group $(M=4.45 .78, S D=1.63)$ were different than the job related group, $M=4.98, S D=1.56, t(131)=-1.92, p=.06$ (two-tailed). These findings suggest that an attorney may pursue more claimant supportive actions when the claim involves an allegation that the selection procedure used was unrelated to the targeted position rather than when the procedure was viewed as related to the targeted position. An additional independent groups t-test revealed the mean action outcome score 
for the merit found condition $(M=5.00, S D=1.54)$ was significantly different than the merit unknown condition, $M=4.45, S D=1.63, t(131)=1.99, p<.05$ (two-tailed). Thus, rejected applicants whose claims were found to be meritorious by the EEOC were perceived more favorably than rejected applicants who did not know the EEOC's decision.

\section{Rejected Applicant Outcomes Aggregate (Representation + Course of legal}

action). A three-way analysis of variance was conducted to explore the impact of protected group category, job relatedness and EEOC decision on rejected applicant (claimant) outcomes. Table 12 displays cell means for the rejected applicant outcomes aggregate.

Table 12

Analysis of Variance Cell Means: Rejected Applicant Outcomes Aggregate

\begin{tabular}{lcccccccccccccc}
\hline & \multicolumn{4}{c}{ Merit Found } & \multicolumn{5}{c}{ Merit Unknown } \\
\cline { 2 - 15 } & \multicolumn{3}{c}{ Job Related } & \multicolumn{2}{c}{ Job Unrelated } & \multicolumn{2}{c}{ Job Related } & \multicolumn{2}{c}{ Job Unrelated } \\
\hline & $n$ & $M$ & $S D$ & $n$ & $M$ & $S D$ & $n$ & $M$ & $S D$ & $n$ & $M$ & $S D$ \\
\hline Minority & 16 & 4.88 & 2.06 & 14 & 6.07 & 1.69 & 16 & 5.25 & 1.44 & 16 & 4.37 & 1.45 \\
Female & 16 & 4.88 & 1.58 & 16 & 6.31 & 1.70 & 16 & 4.50 & 1.97 & 18 & 4.83 & 1.34 \\
\hline
\end{tabular}

Note. $\mathrm{N}=128$. Rejected Applicant Outcomes is an aggregate of Course of legal action and Representation dependent variables, resulting in a 10-point scale, with higher scores representing more aggressive and supportive legal outcomes.

The higher-order interaction effect between protected group, job relatedness and EEOC decision was not statistically significant, $F(1,120)=.67, p=.41$. Simple interaction effects of Protected Group X EEOC Decision, $F(1,120)=.20, p=.65$, and 
Protected Group X Job Relatedness, $F(1,12)=1.51, p=.22$, were not statistically significant.

The simple interaction effect between job relatedness and EEOC decision was found to be significant, $F(1,120)=7.23, p<.01$, partial eta squared $=.06$, suggesting the effect of perceptions of job relatedness on aggregate action outcomes are dependent upon EEOC decision. The interaction was ordinal (see Figure 2), which allows both simple main effects and main effects to be interpreted. A descriptive summary of both job relatedness and EEOC decision simple main effects are displayed in Table 13 and Table 14.

Figure 2

Rejected Applicant Outcomes Aggregate: Job Relatedness X EEOC Decision Interaction Graph

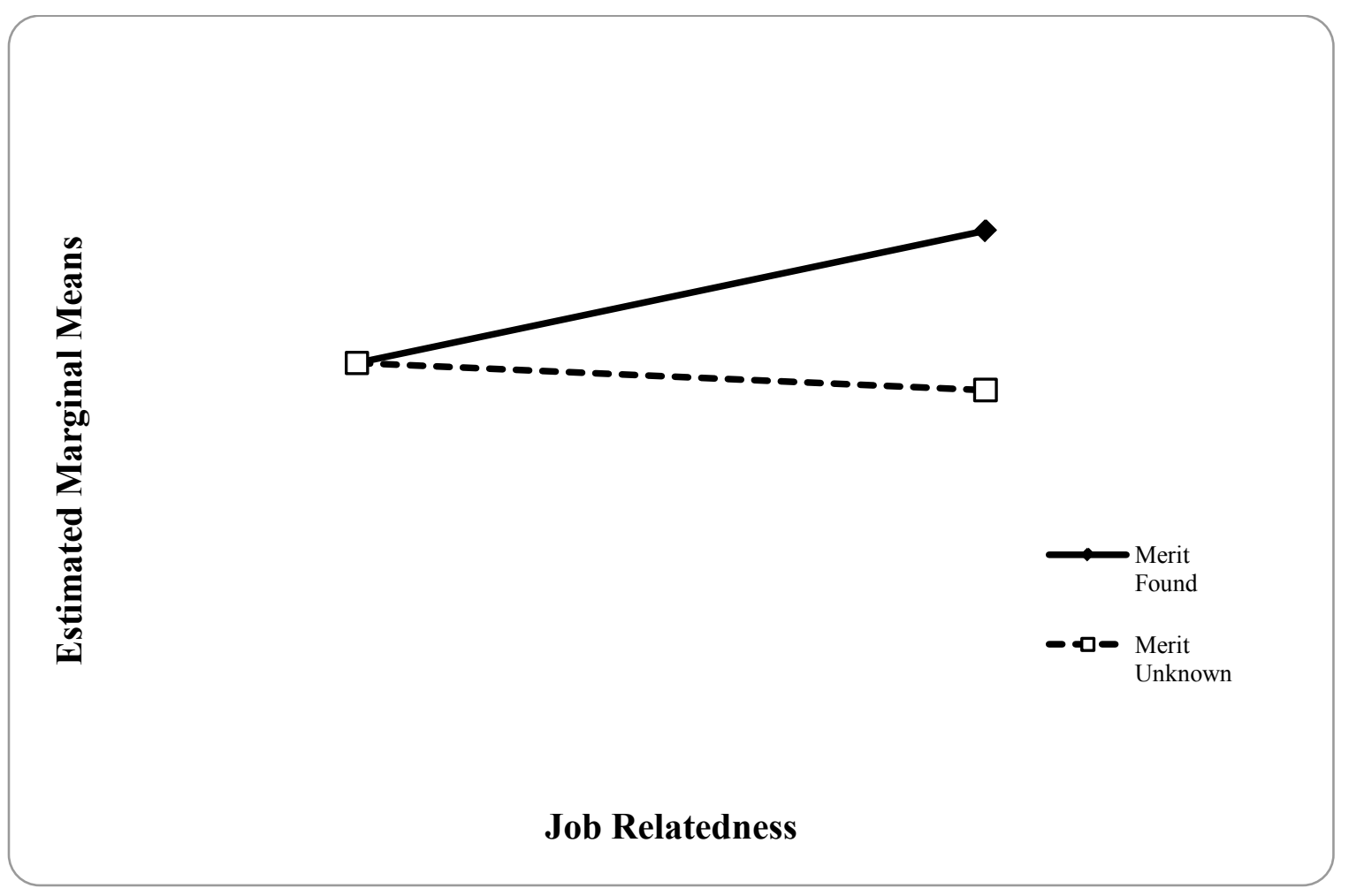

Note. Ordinal interaction. 
A one-way analysis of variance was conducted to test the statistical significance of EEOC decision simple main effects, that is, the effect of EEOC decision on aggregate action outcomes at each level of job relatedness (job related v. job unrelated). To control for Type 1 error rates across the two simple main effects, the alpha level for each was set at $0.025(\alpha / 2=.05 / 2)$. A significant difference between EEOC decision conditions was found at the job unrelated level of job relatedness. A review of the group means indicated that in the job unrelated condition, more claimant supportive action outcomes were selected when the EEOC had found the claim to have merit $(M=6.20, S D=1.67)$ than when the EEOC decision was unknown $(M=4.62, S D=1.39), F(1,63)=17.08, p<$ .001 .

Table 13

Descriptive Summary of EEOC Decision Simple Main Effects: Rejected Applicant Outcomes Aggregate

\begin{tabular}{lccccccccc}
\hline & \multicolumn{3}{c}{ Job Related } & \multicolumn{5}{c}{ Job Unrelated } \\
\cline { 2 - 9 } & $n$ & $M$ & $S D$ & CI & $n$ & $M$ & $S D$ & CI \\
\hline Merit Found & 32 & $4.88^{\mathrm{a}}$ & 1.81 & $\begin{array}{c}(4.22, \\
5.53)\end{array}$ & 30 & $6.20^{\mathrm{a}}$ & 1.67 & $\begin{array}{c}(5.58, \\
\text { Merit Unknown }\end{array}$ \\
\cline { 2 - 8 } & 32 & 4.88 & 1.74 & $\begin{array}{c}(4.25, \\
5.50)\end{array}$ & 34 & 4.62 & 1.39 & $(4.13$, \\
& & & & & & & $5.10)$ \\
\hline
\end{tabular}

Note. $\mathrm{CI}=95 \%$ confidence interval. $\mathrm{a}=$ significant simple main effect.

An additional one-way analysis of variance was conducted to test the statistical significance of job relatedness simple main effects, that is, the effects of applicant perceptions of job relatedness on course of legal action outcomes at each level of EEOC decision (merit found v. merit unknown). To control for Type 1 error rates across the two 
simple main effects, the alpha level for each was set at $0.025(\alpha / 2=.05 / 2)$. A significant difference between job relatedness conditions was found in the merit found level of EEOC decision. A review of the group means indicated that in the merit found condition, more claimant supportive outcomes were selected when the applicant had perceived the selection procedure to be unrelated to the target job $(M=4.88, S D=1.81)$ than when the applicant perceived the selection procedure to be related to the target job $(M=6.02, S D=$ $1.67), F(1,61)=8.95, p<.005$. The calculated effect size was large (eta squared $=.13)$, indicating that actual differences in mean scores between groups was substantial.

The main effect for protected group, $F(1,120)=.002, d=.01$, did not reach statistical significance. However, the main effects of EEOC decision, $F(1,120)=7.24, d$ $=.49$ and job relatedness, $F(1,120)=3.14, d=.32$, were found to be statistically significant. Follow up independent group $t$-tests were conducted to investigate mean differences between groups for both protected group and job relatedness.

Table 14

Descriptive Summary of Job Relatedness Simple Main Effects: Rejected Applicant Outcomes Aggregate

\begin{tabular}{lccccccccc}
\hline & \multicolumn{3}{c}{ Merit Found } & \multicolumn{5}{c}{ Merit Unknown } \\
\cline { 2 - 9 } & $n$ & $M$ & $S D$ & CI & $n$ & $M$ & $S D$ & CI \\
\hline Job Related & 32 & 4.88 & 1.81 & $\begin{array}{c}(4.22, \\
5.53)\end{array}$ & 32 & 4.88 & 1.74 & $(4.25$, \\
Job Unrelated & 30 & $6.20^{\text {a }}$ & 1.67 & $\begin{array}{c}(5.58, \\
6.82)\end{array}$ & 34 & $4.62^{\text {a }}$ & 1.39 & $\begin{array}{c}(4.13, \\
\end{array}$ \\
\cline { 2 - 8 } & & & & & & & $5.10)$ \\
\hline
\end{tabular}

Note. $\mathrm{CI}=95 \%$ confidence interval. a $=$ significant simple main effect. 
The main effect for protected group, $F(1,120)=.002, d=.01$, was not statistically significant. However, the main effects of EEOC decision, $F(1,120)=7.24, d$ $=.49$ and job relatedness, $F(1,120)=3.14, d=.32$, were found to be statistically significant. Follow up independent group $t$-tests were conducted to investigate mean differences between groups for both protected group and job relatedness.

Findings for EEOC decision revealed the mean representation score for the merit found group $(M=5.52, S D=1.85)$ was significantly different than the merit unknown group, $M=4.74, S D=1.56, t(126)=2.56, p<.01$ (two-tailed). These results suggest that an attorney is more likely to select more claimant supportive outcomes when the EEOC has found their claim of discrimination to be meritorious then when the merit determination is unknown. Though not statistically significant, $t(126)=1.58, p=12$, follow-up results for job relatedness demonstrate that more claimant supportive outcomes were selected when the applicant perceived the selection procedure to be unrelated to the target job $(M=5.35, S D=1.71)$ than when the procedure was viewed as related to the target job $(M=4.87, S D=1.76)$.

\section{Exploratory Analyses}

The purpose of the exploratory portion of the questionnaire was to gain insight into several current ambiguities with in the EEO landscape. Specifically, items were developed to investigate issues regarding: (1) validation, (2) scoring procedures and (3) adverse impact strategies. Attorneys were asked to ignore information previously presented in the vignette and indicate how hypothetical pieces of evidence presented by an accused organization would impact their: (1) monetary compensation requests in settlement and (2) overall desire to pursue litigation, as if they were representing a client 
with a legitimate claim of discrimination. Both decision outcomes were rated on a 5-point Likert scale where $1=$ greatly decrease and $5=$ greatly increase. Table 15 displays the items rank ordered within their respective category as well overall for both decision outcomes (monetary compensation and desire to pursue litigation).

Table 15

Rank Order of Validation, Scoring and Adverse Impact Reduction Strategy Scores by Monetary Compensation Request in Settlement and Desire to Pursue Litigation

\begin{tabular}{|c|c|c|c|c|c|c|c|c|}
\hline \multirow[b]{2}{*}{ Organizational Evidence } & \multicolumn{4}{|c|}{ Monetary Compensation } & \multicolumn{4}{|c|}{ Desire to Pursue Litigation } \\
\hline & $n$ & $M$ & $S D$ & Rank & $n$ & $M$ & $S D$ & Rank \\
\hline \multicolumn{9}{|l|}{ Validation } \\
\hline $\begin{array}{l}\text { Content }+ \text { Criterion- } \\
\text { related validity }\end{array}$ & 108 & 1.84 & .98 & $1(1)$ & 108 & 1.64 & .86 & $1(1)$ \\
\hline Criterion-related validity & 109 & 1.96 & .95 & $2(3)$ & 108 & 1.69 & .79 & $2(2)$ \\
\hline Content validity & 109 & 2.06 & .96 & $3(4)$ & 107 & 1.72 & .81 & $3(3)$ \\
\hline Construct validity & 107 & 2.08 & .99 & $4(6)$ & 107 & 1.83 & .89 & $4(5)$ \\
\hline \multicolumn{9}{|l|}{ Scoring Procedures } \\
\hline Minimum Qualifications & 101 & 1.94 & .86 & $1(2)$ & 99 & 1.74 & .79 & $1(4)$ \\
\hline Uniform Guidelines & 101 & 2.14 & .87 & $2(7)$ & 99 & 1.95 & .85 & $2(6)$ \\
\hline Business Relevance & 101 & 2.30 & .84 & $3(9)$ & 99 & 2.07 & .82 & $3(9)$ \\
\hline Burden of Production & 100 & 2.63 & .75 & $4(16)$ & 99 & 2.52 & .83 & $4(14)$ \\
\hline $\begin{array}{l}\text { Relaxed Validation } \\
\text { requirements }\end{array}$ & 100 & 3.20 & .90 & $5(26)$ & 99 & 3.20 & 1.00 & $5(26)$ \\
\hline \multicolumn{9}{|l|}{ Adverse Impact (AI) } \\
\hline Targeted Recruiting & 84 & 2.07 & .88 & $1(5)$ & 84 & 1.96 & .83 & $1(7)$ \\
\hline $\begin{array}{l}\text { Test items equal in } \\
\text { familiarity across } \\
\text { subgroups }\end{array}$ & 87 & 2.16 & .87 & $2(8)$ & 86 & 2.06 & .85 & $2(8)$ \\
\hline $\begin{array}{l}\text { Specific measure of } \\
\text { ability vs. general } \\
\text { measures }\end{array}$ & 88 & 2.35 & .71 & $4(10)$ & 87 & 2.32 & .69 & $3(10)$ \\
\hline $\begin{array}{l}\text { Removed test items that } \\
\text { demonstrated subgroup } \\
\text { difference scores }\end{array}$ & 87 & 2.47 & 1.21 & $3(11)$ & 87 & 2.38 & 1.28 & $4(11)$ \\
\hline
\end{tabular}


Table 15 (continued)

Rank Order of Validation, Scoring and Adverse Impact Reduction Strategy Scores by Monetary Compensation Request in Settlement and Desire to Pursue Litigation

\begin{tabular}{|c|c|c|c|c|c|c|c|c|}
\hline \multirow[b]{2}{*}{ Organizational Evidence } & \multicolumn{4}{|c|}{ Monetary Compensation } & \multicolumn{4}{|c|}{ Desire to Pursue Litigation } \\
\hline & $n$ & $M$ & $S D$ & Rank & $n$ & $M$ & $S D$ & Rank \\
\hline \multicolumn{9}{|l|}{ Adverse Impact (AI) } \\
\hline $\begin{array}{l}\text { Explanations for test } \\
\text { uses provided }\end{array}$ & 83 & 2.51 & .67 & $4(12)$ & 84 & 2.50 & 67 & $6(13)$ \\
\hline $\begin{array}{l}\text { Test-taking training } \\
\text { provided }\end{array}$ & 87 & 2.52 & .73 & $5(13)$ & 84 & 2.45 & .72 & $5(12)$ \\
\hline $\begin{array}{l}\text { Components with both } \\
\text { high AI and predictive } \\
\text { value removed }\end{array}$ & 84 & 2.54 & .92 & $6(14)$ & 84 & 2.57 & .96 & $7(15)$ \\
\hline $\begin{array}{l}\text { Verbal ability } \\
\text { requirements reduced }\end{array}$ & 86 & 2.62 & .77 & $7(15)$ & 84 & 2.58 & .78 & $8(16)$ \\
\hline $\begin{array}{l}\text { Alternative measurement } \\
\text { methods }\end{array}$ & 89 & 2.67 & .84 & $8(17)$ & 88 & 2.74 & .87 & $10(18)$ \\
\hline Retesting permitted & 87 & 2.68 & .72 & $9(18)$ & 88 & 2.66 & .70 & $9(17)$ \\
\hline $\begin{array}{l}\text { Test score banding with } \\
\text { minority preference }\end{array}$ & 87 & 2.77 & 1.01 & $10(19)$ & 87 & 2.82 & 1.11 & 11(19) \\
\hline $\begin{array}{l}\text { Alternative modes of test } \\
\text { presentation }\end{array}$ & 90 & 2.84 & .62 & $11(20)$ & 89 & 2.92 & .63 & $12(20)$ \\
\hline $\begin{array}{l}\text { Multiple hurdle approach } \\
\text { with high AI components } \\
\text { later in process }\end{array}$ & 84 & 2.88 & .84 & $12(21)$ & 83 & 2.95 & .87 & $13(21)$ \\
\hline Test score banding & 90 & 2.94 & .73 & $13(22)$ & 89 & 2.99 & .75 & $14(22)$ \\
\hline $\begin{array}{l}\text { Time limits relaxed or } \\
\text { removed }\end{array}$ & 87 & 3.00 & .73 & $14(23)$ & 86 & 3.01 & .79 & $15(23)$ \\
\hline $\begin{array}{l}\text { Unproctored internet test } \\
\text { used as screening } \\
\text { procedure }\end{array}$ & 90 & 3.06 & .73 & $15(24)$ & 89 & 3.18 & .75 & $16(24)$ \\
\hline $\begin{array}{l}\text { More weight given to } \\
\text { contextual vs. task } \\
\text { performance predictors }\end{array}$ & 88 & 3.16 & .77 & $16(25)$ & 87 & 3.18 & .829 & $17(25)$ \\
\hline
\end{tabular}

Note. Rank data is presented as: Within category Rank (Overall Rank). Ratings provided on a 5-point Likert scale with higher scores demonstrating higher monetary compensation request and higher desire to pursue litigation. 
For the purpose of the present investigation, items with higher mean scores were assumed to hold dire legal consequences; where as items with low mean scores were assumed to be highly legally defensible. A more detailed analysis of implications and best practices in regard to the EEO ambiguities outlined in the literature review will be presented in the discussion chapter to follow. For the purposes of the results section, general trends and rankings will be presented. At a high level, results demonstrated validation evidence that included both content and criterion validity was highly regarded, resulting in both highest category rank in validation procedures and highest rank overall. In regard to the scoring procedures category, the minimum qualifications definition adopted by the third circuit court in Lanning v. Southeastern Pennsylvania Transportation Authority (SEPTA) (1999) (e.g., the business necessity burden was interpreted to mean "minimal qualification necessary for the job") was ranked first, followed by the standard for scoring provided in the Uniform Guidelines (e.g., "cutoff scores used must be reasonable and consistent with normal expectations of acceptable job performance"). The highest rated adverse impact strategy was identified as organizational "efforts to increase and retain the number of qualified minority and female applicants in the hiring pool".

\section{DISCUSSION}

The present study sought to investigate two separable issues in regard to attorney decision-making in cases involving allegedly discriminatory selection procedures. The first portion of the present study sought to understand how characteristics of a rejected applicant claim affect legal action outcomes and perceptions of the rejected applicant. The second portion sought to resolve several key EEO ambiguities in regard to validation 
efforts, scoring procedures and adverse impact reduction strategies. The findings for each purpose will be summarized individually in the sections to follow.

\section{Applicant Statement Characteristics}

Though relationships did not consistently transpire as hypothesized, the results demonstrated general uniformity with original conceptualizations regarding the impact of EEOC decisions and applicant perceptions of job relatedness on attorney decisionmaking. The decision of the EEOC was significantly related to both representation and confidence outcomes, such that attorneys were more likely to represent a rejected applicant and to be confident in favorable client outcomes when the EEOC had found the claim to have merit. Thus, attorneys tended to acquiesce to the merit assessment provided by the EEOC. This result is encouraging as it suggests the regulatory function of the EEOC is generally supported. It also suggests that EEOC merit determinations may forecast subsequent organizational culpability assessments made by any forthcoming legal decision-makers.

The rejected applicants perception of job relatedness was significantly related to both representation and credibility outcomes, such that attorneys were more likely to find applicants who found a selection procedure to be unrelated to the target position more credible and thus, more worthy of representation. Though both job relatedness and EEOC decision were related to representation decisions there were dissimilar relationships with confidence and credibility outcomes. Disparities between confidence and credibility outcomes suggest that job relatedness and EEOC decision may differentially influence claimant perceptions. It is possible that confidence in favorable outcomes may be dependant on validation or support from external legal decision-makers, such as the 
EEOC. Conversely, claim credibility may be more influenced by the information presented by the claimant including allegations that would suggest organizational culpability, such as perceptions of job relatedness, face validity and perceived predictive validity.

In the case of course of legal action and the aggregate of legal outcomes, the impact of the EEOC's decision was dependent upon on the rejected applicants perception of how related the selection procedure was to the targeted position. For course of legal action, EEOC decision and job relatedness simple effect analyses revealed that attorneys chose more claimant supportive actions when the EEOC had found merit and the rejected applicant had found the selection procedure to be unrelated to the job. The interaction between EEOC decision and job relatedness was observed also in the aggregate of legal outcomes analysis. The common interactions in both of these situations suggest that though an initial representation decision may depend more on the decision of the EEOC, subsequent decisions involving next steps in legal action will also involve applicants perceptions of organizational culpability, which in the present study was job relatedness. From this logic, it follows that rejected applicant job relatedness perceptions were related to attorney claim credibility appraisals. If an applicant has a legitimate reason for pursuing legal remedy for discrimination, they are more likely to be found credible. Protected group category was also related to claim credibility outcomes, and in a direction opposite of what was expected; racial minority applicants were found to be more credible than female applicants. Given that credibility outcomes are reflective of attorney appraisals of the claimant it is not surprising that protected group category influenced these judgments. 
There are a few explanations for non-significant findings across remaining dependent variables in regard to differences in applicant protected group category. First, according to EEOC statistics, sex and race based discrimination cases are most frequently claimed. Thus, given the prevalence of both, there may be no difference in whether one basis of claim holds legitimacy over the other. Second, there is possibility that there may be an interaction between attorney characteristics and their propensity or preference for a particular protected group. For example, a female attorney may feel more compelled to represent a female client than a racial minority client, because perhaps she can relate more to the circumstances. To explore this notion, a series of independent group $t$-tests were conducted to investigate the possible influence of attorney characteristics on dependent variable outcomes. There were no significant differences between male and female attorneys across dependent variables. However, in regards to race there were significant differences in representation, $t(84)=2.99, p>.005$, and confidence outcomes, $t(84)=2.03, p>.05$. Minority attorneys $(M=2.87, S D=1.13)$ were more likely to represent a rejected applicant than majority attorneys $(M=2.04, S D=.93)$. Similarly, minority attorneys $(M=2.60, S D=.82)$ were more likely to have confidence in favorable claimant outcomes than majority attorneys $(M=2.08, S D=.91)$. These findings suggest that attorney race may produce more favorable outcomes for clients claiming employment discrimination. Future research may benefit from further investigation of personality or demographic bias in attorney decision-making in regards to employment discrimination. 


\section{Organizational Evidence: Results and Best Practices}

Several key ambiguities in the EEO landscape were identified in the literature review and the results for each of these categories will be discussed in regard to the issues and implications introduced in that chapter. Though purely exploratory, the findings of this portion of the present study are undoubtedly valuable to practitioners, legal professionals and test users alike.

Validity Evidence. There is no general consensus as to which type of validation evidence is most legally defensible. Often, courts disagree with what I/O professionals would regard as preferable evidence. For example, though I/O professionals are proponents of criterion-related validity, the court has often been satisfied with results of content validity, as seen in Brunet v. City of Columbus (1995).

The fact that the combination of both criterion-related and content validity ranked first in the validity evidence category and overall suggests that it is a large mistake for organizations to pursue adverse impact reduction in lieu of thorough validation studies (Gutman, 2000). Though not entirely sufficient in negating the threat of litigation, outcomes would undoubtedly be more favorable for those organizations that could demonstrate reasonable validity then for those who choose to adopt an adverse impact reduction strategy at the expense of lower validity standards.

Scoring Procedures. There is established disagreement as to whether the long time standard for cut off scores provided in the Uniform Guidelines or the minimum qualifications reinterpretation of the business necessity burden provided in Lanning $v$. SEPTA (1999) is best to apply in scoring decisions. The debate holds implications not only for structuring proper scoring strategies but also impacts the types of validity 
evidence needed to support such decisions (Gutman, 2005; Sharf, 1999). In the present investigation the minimum qualifications interpretation ranked higher than the Uniform Guidelines standard, suggesting a shift in legal consciousness from original standards of acceptable scoring to new conceptualizations. The question becomes whether this shift in legal decision-making will hold implications for I/O scientific practice. If so, practitioners will need to provide validity evidence which demonstrates that applicants below a predetermined cutoff score would be unable to perform effectively in order to satisfy burden of persuasion requirements in litigation proceedings (Sharf, 1999).

Strategies for Adverse Impact Reduction. With so many diverse adverse impact reduction strategies to pursue choose from, it is difficult to know which are the most legally defensible. Thus, the present study sought to determine which strategies were most and least preferred by legal decision makers. Interestingly, targeted recruiting (e.g., "Evidence that the organization made efforts to increase and retain the number of qualified minority and female applicants in the hiring pool") ranked highest. This suggests that despite the statistical prowess of other strategies, simply maintaining a pool of diverse and qualified applicants is the best place to start.

The lowest ranked strategy was giving more weight to contextual performance over task performance, which may be because task performance is more tangible and more often viewed as related to job critical knowledge, skills and abilities. Task performance measures have reliably demonstrated subgroup differences because of its relationship with cognitive ability. Thus, it has become common practice to include noncognitive performance indicators as method of negating disparate impact. It should be mentioned that the mean rating indicated the majority of attorneys indicated that this 
strategy would neither increase nor decrease their compensation and litigation decisions. Thus, though concerning this strategy is still viable as long as the organization and practitioner can demonstrate its job relevance.

Interestingly, the second lowest ranked strategy was the use of an unproctored internet test (UIT) as a screening procedure. Within the I/O community, UIT is often criticized as being unethical and susceptible to applicant cheating (e.g.,Tippins, et al., 2006). The present study sample of attorneys seemed to echo this mistrust suggesting that organizations and practitioners should take care when using unproctored internet testing.

\section{Limitations and Future Directions}

There were some attorneys who voiced concern as to how the vignette and survey were framed from a plaintiff's (employee) attorney perspective. Though it was thought knowledge of general employment/labor law could be applied to either perspective, it seemed that employer (defendant) attorneys were uncomfortable in making the inferential leap. Though there may have been a difference in level of comfort across employee and employee attorneys, a series of independent $t$-tests comparing attorney typical representation groups across dependent variable determinations revealed no significant differences. Future research should seek to adopt a more inclusive framework as to avoid this issue. For example, instead of using vignette methodology perhaps more general questions could be created to tap into attorney preferences or decision-making. Further, it may be useful to compare the decision-making processes of employee lawyers and employer lawyers to their respective fields.

The main product an attorney sells is his/her time, and there are differences in how this time is billed. Typically, compensation for services rendered may be contingent 
upon the outcome of the case, or merely assessed by a fixed hourly fee. "Time is money" and it is possible that these distinct payment schedules may differently affect the willingness of an attorney to take on a case. For example, if the attorney is compensated on a contingency basis, the merit of a claim will hold greater importance and relevance in their decision to represent, as payment would not be received if the outcome were not in favor of the client. On the other hand, claim merit may not be a large issue to an attorney who is being paid hourly for time spent on a case, regardless of the outcome. Despite these differences in possible compensation schedules, the present study found statistically significant differences among decision outcomes in regard to independent variables, which suggests that characteristics of an applicants claim are still important. Though legal services will continue to be a profit-driven industry, an attorney's desire to maintain a competitive professional reputation may preclude the desire to garner financial gain from frivolous claims.

The present study adopted a discrimination paradigm that did not include any blatant evidence of intentional discrimination. This choice was deliberate as to manipulate such discrimination would introduce many confounds and significantly expand the scope of the intended purpose. To gain a more broad perspective on attorney decision-making in cases where differential treatment is involved, future research could introduce such evidence into a discrimination paradigm. In addition to understanding how attorneys make decisions in cases involving evidence of differential treatment, this line of research may also hold particular importance in determining if the codification of the identification and causation provisions in CRA-91 will actually result in less instances of 
adverse impact claims as a result of weak intentional discrimination claims (Gutman, 2005).

\section{Implications and Conclusions}

The present study holds several important implications for $\mathrm{I} / \mathrm{O}$ research and practice and for the organizations in which they operate. First and foremost, the present study upholds the need for proper validation and scoring of selection procedures. These processes are important for both maintaining legal compliance and for ensuring that if a procedure is called into question it can be protected. Second, the finding that attorney claim credibility assessments and legal outcome determinations are affected by an applicant's perception of job relatedness supports the importance of eliciting and maintaining positive applicant reactions. Given the finding that test items equal in subgroup familiarity may decrease compensation requests and litigiousness, test professionals and users should make sure that items do not appear to be biased to applicants. Third, practitioners may need to develop strategies to support the minimum qualifications standard, as this may be the new trend followed by courts. Without such evidence an organization may fail to meet burden of persuasion requirements. Finally, it appears organizations should invest more energy in sound validation studies and maintaining a diverse applicant pool before implementing an adverse impact reduction strategy.

Though an applicant may be the only entity for employment discrimination case initiation, there are several decision-making entities (e.g., the EEOC and attorneys) that a claim must filter though in order to qualify for litigation. These entities have the power to end the allegation where it stands or support it though settlement and adversarial 
processes. Legal defensibility then hinges on the extent to which researchers, practitioners and organizations alike make efforts to understand how these decisions are made and further, apply of this knowledge towards the creation of future selection procedures. This study takes the first step in contributing to a more comprehensive understanding of the decision-making processes of various stakeholders in employment discrimination cases beyond the applicant by investigating the factors that influence attorney decisions. 


\section{REFERENCES}

American Educational Research Association, American Psychological Association, \& National Council on Measurement in Education. (1999). Standards for educational and psychological testing. Washington, DC: American Educational Research Association.

Bauer, T.N., Maertz, C.P., Dolen, M.R., Campion, M.A. (1998). Longitudinal Assessment of Applicant Reactions to Employment Testing and Test Outcome Feedback. Journal of Applied Psychology, 86, 892-903. doi:10.1037/00219010.83.6.892

Berry, L.M. (2003). Employee Selection. Belmont, CA: Thompson/Wadsworth.

Biddle, D.A. Kuthy, J., \& Nooren, P.M. (2003). Protecting your agency against equal employment opportunity (EEO) litigation related to selection and promotion practices. Law Enforcement Executive Forum, 3, 5-14.

Borden, L.W. \& Sharf, J.C. (2007). Developing legally defensible content valid selection procedures. In D.L. Whetzel \& G.R. Wheaton (Eds.) Applied measurement: Industrial psychology in human resources management (pp. 385-401). Mahwah, NJ: Lawrence Erlbaum Associates, Inc.

Camera, W.J. (1996). Fairness and public policy in employment testing: Influences from a professional association. In Richard S. Barrett (Ed.), Fair employment strategies in human resource management (pp. 3-11). Westport, CT: Quorum Books.

Cascio, W.F. (1987). Applied psychology in personnel management (3rd ed.). Englewood Cliffs, NJ: Prentice-Hall.

Cascio, W.F. (2000). Costing human resources. Cincinnati, OH: South-Western.

Cascio, W.F., \& Aguinis, H. (2005). Applied Psychology in Human Resource Management (6th ed.). Upper Saddle River, NJ: Pearson Education, Inc.

Cascio, W.F., Outtz, J., Zedeck, S., \& Goldstein, I.L. (1991). Statistical implications of six methods of test score use in personnel selection. Human Performance, 4, 233264. doi:10.1207/s15327043hup0404_1

Civil Rights Act of 1964 (Title VII), 42 U.S.C. $§ 2000$ e (1964).

Civil Rights Act of 1991 (CRA-91), Pub. L. No. 102-118, 105 Stat. 1071 (1991).

Cleary, T.A. (1968). Test bias: Prediction of grades of negro and white students in integrated colleges. Journal of Educational Measurement, 5, 115-124. doi:10.1111/j.1745-3984.1968.tb00613.x 
Colquitt, J.A., Conlon, D.E., Wesson, M.J., Porter, C.O.L.H., \& Ng, K.Y (2001). Justice at the millennium: A meta-analytic review of 25 years of organizational justice research. Journal of Applied Psychology, 86, 425-445.

EEOC. (2009a). Job bias charges approach record high in fiscal year 2009, EEOC reports. Retrieved from: http://www.eeoc.gov/eeoc/newsroom/release/1-6-10.cfm.

EEOC. (2009b). Race-based charges. http://www.eeoc.gov/eeoc/statistics/enforcement/race.cfm.

EEOC. (2009c). Sex-based charges. http://www.eeoc.gov/eeoc/statistics/enforcement/sex.cfm.

EEOC. (2009d). Charge statistics. http://www.eeoc.gov/eeoc/statistics/enforcement/charges.cfm

Gilliland, S.W. (1993). Perceived Fairness of Selection Systems: An Organizational Justice Perspective. Academy of Management, 18, 694-734. doi:10.2307/258595

Gilliland, S.W. (1994). Effects of Procedural and Distributive Justice on Reactions to a Selection System. Journal of Applied Psychology, 79, 691-701. doi:10.1037/0021-9010.79.5.691

Goldman, B.M., Gutek, B.A., Stein, J.H., \& Lewis, K. (2006). Employment discrimination in organizations: Antecedents and consequences. Journal of Management, 32, 786-830. doi:10.1177/0149206306293544

Guion, R.M. (1966). Employment tests and discriminatory hiring. Industrial Relations, 5, 20-37.

Gutman, A. (2000). EEO Law and Personnel Practices (2nd. Ed.). Thousand Oaks, CA: Sage Publications.

Gutman, A. (2005). Adverse impact: Judicial, regulatory and statutory authority. In F.J. Landy (Ed.) Employment Discrimination Litigation: Behavioral, Quantitative and Legal Perspectives (pp. 20-46). San Francisco, CA: Jossey-Bass.

Gutman, A. (2009). Major EEO issues relating to personnel selection decisions. Human Resource Management Review, 19, 232-250.

Harris, M.M, Lievens, F., \& Van Hoye, G. (2004). "I think they discriminated against me": Using prototype theory for understanding perceived discrimination in selection and promotion situations. International Journal of Selection and Assessment, 12, 54-65. 
Hausknecht, J.P., Day, D.D., Thomas, S.C. (2004). Applicant Reactions to Selection Procedures: An Updated Model and Meta-Analysis. Personnel Psychology, 57, 639-683. doi: 10.1111/j.1744-6570.2004.00003.x

Hirberger, W. (1996). Current evidentiary issues in employment litigation. Employee Relations Law Journal, 22, 31-56.

Hough, L.M., Oswald, F.L., \& Ployhart, R.E. (2001). Determinants, detection and amelioration of adverse impact in personnel selection procedures: Issues, evidence and lessons learned. International Journal of Selection and Assessment, 9, 152-194. doi:10.1111/1468-2389.00171

Howell, D.C. (2002). Statistical Methods for Psychology (5 ${ }^{\text {th }}$ ed.). Pacific Grove, CA: Duxbury.

Jeanneret, R. (2005). Professional and technical authorities and guidelines. In F.J. Landy (Ed.) Employment Discrimination Litigation: Behavioral, Quantitative and Legal Perspectives (pp. 47-100). San Francisco, CA: Jossey-Bass.

Landy, F.J. (2005). Phases of employment litigation. In F.J. Landy (Ed.) Employment Discrimination Litigation: Behavioral, Quantitative and Legal Perspectives (pp. 47-100). San Francisco, CA: Jossey-Bass.

Lind, E.A. (1997). Litigation and claiming in organizations: Antisocial behavior or quest for justice? In R.A. Giacalone \& Greenberg (Eds.) Antisocial behavior in organizations: (pp. 150-171). Thousand Oaks, CA: Sage.

Osterlind, S.J. (2006). Modern measurement: Theory, principles, and applications of mental appraisal. Upper Saddle River, NJ: Pearson Education, Inc.

Ployhart, R.E., Schneider, B. \& Schmitt, N. (2006). Staffing organizations: Contemporary Practice and Theory ( $3^{\text {rd }}$ Ed.). Mahwah, NJ: Lawrence Erlbaum Associates, Publishers.

Ployhart, R.E. \& Holtz, B.C. (2008). The diversity-validity dilemma: Strategies for reducing racioethnic and sex sub group differences and adverse impact in selection. Personnel Psychology, 61, 153 -172. doi:10.1111/j.17446570.2008.00109.x

Pyburn, K.M., Ployhart, R.E., \& Kravitz, D.A. (2008). The diversity-validity dilemma: overview and legal context. Personnel Psychology, 61, 143-151. doi:10.1111/j.1744-6570.2008.00108.x

Ryan, A.M. \& Ployhart, R.E. (2000). Applicant perception of selection procedures and decisions: A critical review and agenda for the future. Journal of Management, 26, 565-606. doi:10.1177/014920630002600308 
Ryan, A.M. \& Tippins, N.T. (2004). Attracting and selecting: What psychological research tells us. Human Resource Management, 43, 305-318.

doi:10.1002/hrm.20026

Schmidt, F.L. \& Hunter, J.E. (1998). The validity and utility of selection methods in personnel psychology. Practical and theoretical implications of 85 years of research findings. Psychological Bulletin, 124, 262-274. doi:10.1037/00332909.124.2.262

Schriesheim, C.A., Powers, K.J., Scandura, T.A., Gardiner, C.C., \& Lankau, M.J. (1993). Improving construct measurement in management research: Comments and a quantitative approach for assessing the theoretical adequacy of paper-and-pencil survey-type instruments. Journal of Management, 19, 385-415. doi:10.1177/014920639301900208

Sharf, J. (1999). Third circuit's Lanning v. SEPTA decision: "Business necessity" requires setting minimum standards. The Industrial-Organizational Psychologist, 37, 138-49.

Sharf, J.C. \& Jones, D.P. (2000). Employment risk management. In J.F. Kehoe (Ed.) Managing selection in changing organizations: Human Resource Strategies (pp. 271-318). San Francisco, CA: Jossey-Bass.

Siskin, B.R. \& Trippi, J. (2005). Statistical Issues in Litigation. In F.J. Landy (Ed.) Employment Discrimination Litigation: Behavioral, Quantitative and Legal Perspectives (pp. 132-166). San Francisco, CA: Jossey-Bass.

Society for Industrial and Organizational Psychology. (2003). Principles for the validation and use of personnel selection procedures $\left(4^{\text {th }} \mathrm{ed}\right.$.). Bowling Green, $\mathrm{OH}$ : Author.

Smither, J.W., Reilly, R.R., Millsap, R.E., Pearlman, K. \& Stoffey, R.W. (1993). Applicant reactions to selection procedures. Personnel Psychology, 46, 49-76. doi:10.1111/j.1744-6570.1993.tb00867.x

Terpstra, D.E. \& Kethley, R.B. (2002). Organizations' relative degree of exposure to selection discrimination litigation. Public Personnel Management, 31, 277-292.

Terpstra, D.E., Mohamed, A.A., \& Kethley, R.B. (1999). An analysis of federal court cases involving nine selection devices. International Journal of Selection and Assessment, 7, 26-34. doi:10.1111/1468-2389.00101

Thibodeaux, H.F. \& Kudisch. (2003). The relationship between applicant reactions, the likelihood of complaints, and organizational attractiveness. Journal of Business and Psychology, 18, 247-257. doi:10.1023/A:1027353216186 
Tippins, N.T., Beaty, J., Drasgow, F., Gibson, W.M.; Pearlman, et al. (2006). Unproctored internet testing in employment settings. Personnel Psychology, 59, 189-225. doi:10.1111/j.1744-6570.2006.00909.x

Truxillo, D.M., Bauer, T.N., Campion, M.A., Paronto, M.E. (2006). A Field Study of the Role of Big Five Personality in Applicant Perceptions of Selection Fairness, Self, and the Hiring Organization. International Journal of Selection and Assessment, 14, 269-277. doi:10.1111/j.1468-2389.2006.00351.x

Uniform Guidelines on Employee Selection Procedures (1978). Federal Register, 43, 38290-38315.

Van Iddekinge, C. H., \& Ployhart, R. E. (2008). Developments in the criterion-related validation of selection procedures: A critical review and recommendations for practice. Personnel Psychology, 61, 871-925. doi:10.1111/j.17446570.2008.00133.x

Viswesvaran, C. \& Ones, D. (2004). Importance of Perceived Personnel Selection System Fairness Determinants: Relations with Demographic, Personality and Job Characteristics. International Journal of Selection and Assessment, 12, 172-186. doi:10.1111/j.0965-075X.2004.00272.x

Williamson, L.G., Campion, J.E., Malos, S.B., Roehling, M.A., \& Campion, M.A. (1997). Employment interview on trial: Linking interview structure with litigation outcomes. Journal of Applied Psychology, 82, 900-912. doi:10.1037/00219010.82.6.900

\section{Legal Cases}

Albemarle Paper Co. v. Moody, 422 U.S. 405 (1975).

Atonio v. Wards Cove Packing Company, 768 F.2d 1120 (1993).

Bridgeport Guardians, Inc. v. City of Bridgeport, 933 F.2d 1140 (2d. Cir 1991).

Brunet v. City of Columbus, 58 F.2d 251 (6th Cir. 1995).

Griggs v. Duke Power Co., 401 U.S. 424 (1971).

Guardians of New York v. Civil Service Commission, 630 F.2d 79 (2d Cir. 1980).

Lanning v. Southeastern Pennsylvania Transportation Authority, 181 F.3d 478 (3rd. Cir. 1999).

McDonnell Douglas Corp. v. Green, 411 U.S. 792 (1973).

Texas Department of Community Affairs v. Burdine, 450 U.S. 248 (1981). 
Wards Cove Packing Company v. Atonio, 490 U.S. 642 (1989).

Watson v. Fort Worth Bank and Trust, 487 U.S. 977 (1988). 


\section{APPENDICES}

\section{Vignettes}

\section{Condition 1: Job Related/EEOC Merit Found/Racial Minority Applicant.}

A potential client approaches you with a request for representation in an employment selection dispute. The potential client is a minority who recently applied for an Accounting position at a local organization seeking applicants, but was denied employment. The potential client feels that this decision was inequitable and is seeking your assistance to remedy the issue with the hiring organization. The rejected applicant provides you with the following statements:

- "I received my 4-year Bachelor of Accounting Degree from a top-tier university in 1999 and was employed immediately after graduation as a Staff Accountant for a large accounting firm. With the firm's support, I became a Certified Public Accountant (CPA) in 2002. A few months ago I decided to relocate, so I had to leave my current job and seek employment near my new residence."

- "I responded to an Accountant opening at ABC Accounting Firm in April 2010. After receiving my resume and application I was contacted by a hiring manager who asked me to complete a battery of tests, which, I was told, would determine if I was fit to be hired. The battery included a job knowledge test and a personality inventory. Soon after, I was told I was rejected because I was a mismatch to what the organization was looking for, despite my qualifications."

- "In terms of the content of the selection test, I felt the items were related the level of performance expected of a competent accountant. It was clear that a person who did well on these tests would do well on the job. However, I suspect the method in which the items were scored may be detrimental to minority applicants, perhaps because they do not account for the unique experiences of minorities."

- "To remedy my suspicion, I filed a discrimination charge with the EEOC in May of 2010, a week after I was rejected for employment at ABC Accounting Firm. Though my charge was found to have merit after an initial investigation, the EEOC informed me they were unable to successfully conciliate with the employer. I was then issued a right-to-sue letter and told I could seek private representation."

\section{Condition 2: Job Related/EEOC Merit Unknown/Racial Minority Applicant.}

A potential client approaches you with a request for representation in an employment selection dispute. The potential client is a minority who recently applied for an Accounting position at a local organization seeking applicants, but was denied employment. The potential client feels that this decision was inequitable and is seeking 
your assistance to remedy the issue with the hiring organization. The rejected applicant provides you with the following statements:

- "I received my 4-year Bachelor of Accounting Degree from a top-tier university in 1999 and was employed immediately after graduation as a Staff Accountant for a large accounting firm. With the firm's support, I became a Certified Public Accountant (CPA) in 2002. A few months ago I decided to relocate, so I had to leave my current job and seek employment near my new residence."

- "I responded to an Accountant opening at ABC Accounting Firm in April 2010. After receiving my resume and application I was contacted by a hiring manager who asked to me complete a battery of tests, which, I was told, would determine if I was fit to be hired. The battery included a job knowledge test and a personality inventory. Soon after, I was told I was rejected because I was a mismatch to what the organization was looking for, despite my qualifications."

- "In terms of the content of the selection test, I felt the items were related the level of performance expected of a competent accountant. It was clear that a person who did well on these tests would do well on the job. However, I suspect the method in which the items were scored may be detrimental to minority applicants, perhaps because they do not account for the unique experiences of minorities."

- "To remedy my suspicion, I filed a discrimination charge with the EEOC in May of 2010, a week after I was rejected for employment at ABC Accounting Firm. The 180 day time limit is fast approaching and the EEOC has yet to inform me of the results of the investigation. I am planning on requesting a right-to-sue letter so I can seek private representation."

\section{Condition 3: Job Unrelated/EEOC Merit Found/Racial Minority Applicant.}

A potential client approaches you with a request for representation in an employment selection dispute. The potential client is a minority who recently applied for an Accounting position at a local organization seeking applicants, but was denied employment. The potential client feels that this decision was inequitable and is seeking your assistance to remedy the issue with the hiring organization. The rejected applicant provides you with the following statements:

- "I received my 4-year Bachelor of Accounting Degree from a top-tier university in 1999 and was employed immediately after graduation as a Staff Accountant for a large accounting firm. With the firm's support, I became a Certified Public Accountant (CPA) in 2002. A few months ago I decided to relocate, so I had to leave my current job and seek employment near my new residence."

- "I responded to an Accountant opening at ABC Accounting Firm in April 2010. After receiving my resume and application I was contacted by a hiring manager 
who asked to me complete a battery of tests, which, I was told, would determine if I was fit to be hired. The battery included a job knowledge test and a personality inventory. Soon after, I was told I was rejected because I was a mismatch to what the organization was looking for, despite my qualifications."

- "In terms of the content of the selection test I did not understand how the items were related to performance expectations of a competent accountant. Generally, the items seemed to be unrelated to the job. Further, it was unclear to me that a person who did well on these tests would do well on the job. I also suspect the method in which the items were scored may be detrimental to minority applicants, perhaps because they do not account for the unique experiences of minorities."

- "To remedy my suspicion, I filed a discrimination charge with the EEOC in May of 2010, a week after I was rejected for employment at ABC Accounting Firm. Though my charge was found to have merit after an initial investigation, the EEOC informed me they were unable to successfully conciliate with the employer. I was then issued a right-to-sue letter and told I could seek private representation."

\section{Condition 4: Job Unrelated/EEOC Merit Unknown/Racial Minority Applicant.}

A potential client approaches you with a request for representation in an employment selection dispute. The potential client is a minority who recently applied for an Accounting position at a local organization seeking applicants, but was denied employment. The potential client feels that this decision was inequitable and is seeking your assistance to remedy the issue with the hiring organization. The rejected applicant provides you with the following statements:

- 'I received my 4-year Bachelor of Accounting Degree from a top-tier university in 1999 and was employed immediately after graduation as a Staff Accountant for a large accounting firm. With the firm's support, I became a Certified Public Accountant (CPA) in 2002. Unfortunately, due to my spouse being relocated for work I had to leave my job and apply for a replacement at our new location."

- "I responded to an Accountant opening at ABC Accounting Firm in April 2010. After receiving my resume and application I was contacted by a hiring manager who asked me to complete a battery of tests, which, I was told, would determine if I was fit to be hired. The battery included a job knowledge test and a personality inventory. Soon after, I was told I was rejected because I was a mismatch to what the organization was looking for, despite my qualifications."

- "In terms of the content of the selection test I did not understand how the items were related to performance expectations of a competent accountant. Generally, the items seemed to be unrelated to the job. Further, it was unclear to me that a person who did well on these tests would do well on the job. I also suspect the 
method in which the items were scored may be detrimental to minority applicants. Perhaps because they do not account for the unique experiences of minorities."

- "To remedy my suspicion, I filed a discrimination charge with the EEOC in May of 2010, a week after I was rejected for employment at ABC Accounting Firm. The 180 day time limit is fast approaching and the EEOC has yet to inform me of the results of the investigation. I am planning on requesting a right-to-sue letter so I can seek private representation."

\section{Condition 5: Job Related/EEOC Merit Found/Female Applicant.}

A potential client approaches you with a request for representation in an employment selection dispute. The potential client is a minority who recently applied for an Accounting position at a local organization seeking applicants, but was denied employment. The potential client feels that this decision was inequitable and is seeking your assistance to remedy the issue with the hiring organization. The rejected applicant provides you with the following statements:

- "I received my 4-year Bachelor of Accounting Degree from a top-tier university in 1999 and was employed immediately after graduation as a Staff Accountant for a large accounting firm. With the firms support, I became a Certified Public Accountant (CPA) in 2002. A few months ago I decided to relocate, so I had to leave my current job and seek employment near my new residence."

- "I responded to an Accountant opening at ABC Accounting Firm in April 2010. After receiving my resume and application I was contacted by a hiring manager who asked me to complete a battery of tests, which, I was told, would determine if I was fit to be hired. The battery included a job knowledge test and a personality inventory. Soon after, I was told I was rejected because I was a mismatch to what the organization was looking for, despite my qualifications."

- "In terms of the content of the selection test, I felt the items were related the level of performance expected of a competent accountant. It was clear that a person who did well on these tests would do well on the job. However, I suspect the method in which the items were scored may be detrimental to female applicants, perhaps because they do not account for the unique experiences of females."

- "To remedy my suspicion, I filed a discrimination charge with the EEOC in May of 2010, a week after I was rejected for employment at ABC Accounting Firm. Though my charge was found to have merit after an initial investigation, the EEOC informed me they were unable to successfully conciliate with the employer. I was issued a right-to-sue letter and told I could seek private representation." 


\section{Condition 6: Job Related/EEOC Merit Unknown/Female Applicant.}

A potential client approaches you with a request for representation in an employment selection dispute. The potential client is a minority who recently applied for an Accounting position at a local organization seeking applicants, but was denied employment. The potential client feels that this decision was inequitable and is seeking your assistance to remedy the issue with the hiring organization. The rejected applicant provides you with the following statements:

- "I received my 4-year Bachelor of Accounting Degree from a top-tier university in 1999 and was employed immediately after graduation as a Staff Accountant for a large accounting firm. With the firm's support, I became a Certified Public Accountant (CPA) in 2002. A few months ago I decided to relocate, so I had to leave my current job and seek employment near my new residence."

- "I responded to an Accountant opening at ABC Accounting Firm in April 2010. After receiving my resume and application I was contacted by a hiring manager who asked me to complete a battery of tests, which, I was told, would determine if I was fit to be hired. The battery included a job knowledge test and a personality inventory. Soon after, I was told I was rejected because I was a mismatch to what the organization was looking for, despite my qualifications."

- "In terms of the content of the selection test, I felt the items were related the level of performance expected of a competent accountant. It was clear that a person who did well on these tests would do well on the job. However, I suspect the method in which the items were scored may be detrimental to female applicants, perhaps because they do not account for the unique experiences of females."

- "To remedy my suspicion, I filed a discrimination charge with the EEOC in May of 2010, a week after I was rejected for employment at ABC Accounting Firm. The 180 day time limit is fast approaching and the EEOC has yet to inform me of the results of the investigation. I am planning on requesting a right-to-sue letter so I can seek private representation."

\section{Condition 7: Job Unrelated/EEOC Merit Found/Female Applicant.}

A potential client approaches you with a request for representation in an employment selection dispute. The potential client is a minority who recently applied for an Accounting position at a local organization seeking applicants, but was denied employment. The potential client feels that this decision was inequitable and is seeking your assistance to remedy the issue with the hiring organization. The rejected applicant provides you with the following statements:

- "I received my 4-year Bachelor of Accounting Degree from a top-tier university in 1999 and was employed immediately after graduation as a Staff Accountant for 
a large accounting firm. With the firm's support, I became a Certified Public Accountant (CPA) in 2002. A few months ago I decided to relocate, so I had to leave my current job and seek employment near my new residence."

- "I responded to an Accountant opening at ABC Accounting Firm in April 2010. After receiving my resume and application I was contacted by a hiring manager who asked me to complete a battery of tests, which, I was told, would determine if I was fit to be hired. The battery included a job knowledge test and a personality inventory. Soon after, I was told I was rejected because I was a mismatch to what the organization was looking for, despite my qualifications."

- "In terms of the content of the selection test I did not understand how the items were related to performance expectations of a competent accountant. Generally, the items seemed to be unrelated to the job. Further, it was unclear to me that a person who did well on these tests would do well on the job. I also suspect the method in which the items were scored may be detrimental to female applicants, perhaps because they do not account for the unique experiences of females."

- "To remedy my suspicion, I filed a discrimination charge with the EEOC in May of 2010, a week after I was rejected for employment at ABC Accounting Firm. Though my charge was found to have merit after an initial investigation, the EEOC informed me they were unable to successfully conciliate with the employer. I was then issued a right-to-sue letter and told I could seek private representation."

\section{Condition 8: Job Unrelated/EEOC Merit Unknown/Female Applicant.}

A potential client approaches you with a request for representation in an employment selection dispute. The potential client is a minority who recently applied for an Accounting position at a local organization seeking applicants, but was denied employment. The potential client feels that this decision was inequitable and is seeking your assistance to remedy the issue with the hiring organization. The rejected applicant provides you with the following statements:

- "I received my 4-year Bachelor of Accounting Degree from a top-tier university in 1999 and was employed immediately after graduation as a Staff Accountant for a large accounting firm. With the firm's support, I became a Certified Public Accountant (CPA) in 2002. A few months ago I decided to relocate, so I had to leave my current job and seek employment near my new residence."

- "I responded to an Accountant opening at ABC Accounting Firm in April 2010. After receiving my resume and application I was contacted by a hiring manager who asked me to complete a battery of tests, which, I was told, would determine if I was fit to be hired. The battery included a job knowledge test and a personality 
inventory. Soon after, I was told I was rejected because I was a mismatch to what the organization was looking for, despite my qualifications."

- "In terms of the content of the selection test I did not understand how the items were related to performance expectations of a competent accountant. Generally, the items seemed to be unrelated to the job. Further, it was unclear to me that a person who did well on these tests would do well on the job. I also suspect the method in which the items were scored may be detrimental to female applicants, perhaps because they do not account for the unique experiences of females."

- "To remedy my suspicion, I filed a discrimination charge with the EEOC in May of 2010, a week after I was rejected for employment at ABC Accounting Firm. The 180 day time limit is fast approaching and the EEOC has yet to inform me of the results of the investigation. I am planning on requesting a right-to-sue letter so I can seek private representation."

\section{Questionnaire}

\section{Part I. Hypothesis Testing.}

Dependent measures. Please use the information provided in the potential client's statement to answer the following questions.

1. Please indicate the likelihood that you would choose to retain this potential client for representation using the provided scale.

\begin{tabular}{|c|c|c|c|c|}
\hline 1 & 2 & 3 & 4 & 5 \\
\hline Not at all likely & Slightly likely & Moderately likely & Quite a bit likely & Extremely likely \\
\hline
\end{tabular}

2. The event you choose to represent the rejected applicant, how confident would you be that the outcome would be in your favor?

\begin{tabular}{|c|c|c|c|c|}
\hline 1 & 2 & 3 & 4 & 5 \\
\hline $\begin{array}{l}\text { Not at all } \\
\text { confident }\end{array}$ & Slightly confident & $\begin{array}{c}\text { Moderately } \\
\text { confident }\end{array}$ & $\begin{array}{c}\text { Quite a bit } \\
\text { confident }\end{array}$ & $\begin{array}{c}\text { Extremely } \\
\text { confident }\end{array}$ \\
\hline
\end{tabular}

3. In your opinion, how credible was the rejected applicant's claim?

\begin{tabular}{|c|c|c|c|c|}
\hline 1 & 2 & 3 & 4 & 5 \\
\hline Not at all credible & Slightly credible & $\begin{array}{c}\text { Moderately } \\
\text { credible }\end{array}$ & $\begin{array}{c}\text { Quite a bit } \\
\text { credible }\end{array}$ & Extremely credible \\
\hline
\end{tabular}

4. Please select which of the following courses of action you would be most likely to pursue given the information presented by the rejected applicant. 
$\square$ Recommend the applicant dismiss the case.

Contact the organization for further information about the selection procedure used.

Immediately file the case.

\section{Manipulation Checks.}

\section{True or False}

5. An applicant who found a selection procedure to be job related might say, "The content of this test was clearly related to the content of the job. It is clear that a person who did well on this test would do well on the job."

$\square$ True

$\square$ False

6. The EEOC will provide a right-to-sue letter to a claiming party whenever one is requested.

$\square$ True

$\square$ False

7. The EEOC will provide a right to sue letter to a claiming party if (1) it is approaching 180 days and no decision has been made and (2) if merit has been found, but conciliation was unsuccessful.

$\square$ True

False

8. The rejected applicant was asked by the hiring manager to complete a situational judgment test.

$\square$ True

$\square$ False

\section{Multiple Choice}

9. What type of job was the rejected applicant applying for?

Architectural Drafter

$\square$ Accountant

$\square$ Anesthesiologist

Art Teacher 
Condition respective counter-scenario questions. Please indicate how your decision to represent the rejected applicant would have been impacted given the following pieces of information using the provided scale.

\begin{tabular}{|c|c|c|c|c|}
\hline 1 & 2 & 3 & 4 & 5 \\
\hline $\begin{array}{c}\text { Greatly decrease } \\
\text { likelihood of } \\
\text { representation }\end{array}$ & $\begin{array}{c}\text { Moderately } \\
\text { decrease } \\
\text { likelihood of } \\
\text { representation }\end{array}$ & $\begin{array}{c}\text { Neither increase } \\
\text { nor decrease } \\
\text { likelihood of } \\
\text { representation }\end{array}$ & $\begin{array}{c}\text { Moderately } \\
\text { increase } \\
\text { likelihood of } \\
\text { representation }\end{array}$ & $\begin{array}{c}\text { Greatly increase } \\
\text { likelihood of } \\
\text { representation }\end{array}$ \\
\hline
\end{tabular}

\section{General}

All Conditions

The applicant filed a claim with the EEOC, but the EEOC determined the applicant had no merit.

The applicant was a male.

The applicant was a non-minority

\section{Job Relatedness}

\section{Condition 1, 2, $5 \& 6$}

The applicant informed you that he/she perceived the selection test items to be unrelated to the job they applied for (e.g. The applicant stated: "In terms of the content of the selection test I did not understand how the items were related to performance expectations of a competent accountant. Generally, the items seemed to be unrelated to the job. Further, it was unclear to me that a person who did well on these tests would do well on the job").

\section{Condition 3, 4, $7 \& 8$}

The applicant informed you that they perceived the selection test items to be related to the job they applied for (e.g. The applicant stated: "In terms of the content of the selection test, I felt the items were related the level of performance expected of a competent accountant. It was clear that a person who did well on these tests would do well on the job").

\section{Protected Group Category}

Conditions 1, 2, $3 \& 4$

The applicant was a female.

Conditions 5, $6,7 \& 8$

The applicant was a minority.

\section{EEOC Decision}

Conditions 1, 3, $5 \& 7$

The applicant filed a claim with the EEOC, but the EEOC has yet to provide any information regarding the results of the investigation and the 180-day time limit is fast approaching. 
Conditions 2, 4, $6 \& 8$

The applicant filed a report with the EEOC, the claim was found to have reasonable cause, but the EEOC was unable to successfully conciliate with the organization.

\section{Part II. Organizational Evidence.}

The next part of this questionnaire is intended to understand your general perceptions of legal issues in employment discrimination cases. Please disregard the previously provided information regarding the potential applicant to answer the following questions. The following pieces of information are meant to represent possible pieces of evidence demonstrated in discovery by the organization accused of employment discrimination.

To the best of your ability, please indicate how each of the following pieces of evidence would impact your initial monetary compensation request in a settlement negotiation with the organization using the following scale:

\begin{tabular}{|c|c|c|c|c|}
\hline 1 & 2 & 3 & 4 & 5 \\
\hline $\begin{array}{c}\text { Greatly decrease } \\
\text { \$ amount }\end{array}$ & $\begin{array}{c}\text { Moderately } \\
\text { decrease } \$ \\
\text { amount }\end{array}$ & $\begin{array}{c}\text { Neither increase } \\
\text { nor decrease } \$ \\
\text { amount }\end{array}$ & $\begin{array}{c}\text { Moderately } \\
\text { increase \$ amount }\end{array}$ & $\begin{array}{c}\text { Greatly increase } \\
\text { \$ amount }\end{array}$ \\
\hline
\end{tabular}

To the best of your ability, please indicate how each of the following pieces of evidence would impact your willingness to file suit against the organization using the following scale:

\begin{tabular}{|c|c|c|c|c|}
\hline 1 & 2 & 3 & 4 & 5 \\
\hline $\begin{array}{c}\text { Greatly decrease } \\
\text { desire }\end{array}$ & $\begin{array}{c}\text { Moderately } \\
\text { decrease desire }\end{array}$ & $\begin{array}{c}\text { Neither increase } \\
\text { nor decrease } \\
\text { desire }\end{array}$ & $\begin{array}{c}\text { Moderately } \\
\text { increase desire }\end{array}$ & $\begin{array}{c}\text { Greatly increase } \\
\text { desire }\end{array}$ \\
\hline
\end{tabular}

\section{Validity Evidence Items.}

1. Evidence that the content of selection procedure is representative of and related to expected performance on the job. (Content Validity)

2. Evidence that test scores are predictive of important elements of job performance. (Criterion-related Validity)

3. Evidence that the selection procedure measured a construct critical to effective job performance. (Construct Validity)

4. Evidence that the content of selection procedure is representative of and related to expected performance on the job and that scores are predictive of important elements of job performance. (Content + Criterion-related) 


\section{Scoring Procedures Items.}

1. Evidence that that the scoring procedure used was related to an important business goal or public interest. (Business Relevance - Fitzpatrick v. City of Atlanta)

2. Evidence that cutoff scores used were reasonable and consistent with normal expectations of acceptable job performance. (Uniform Guidelines)

3. Evidence that the cut score represented a minimum qualification, such that most applicants below the set cutoff could not succeed on the job. (Minimum Qualifications - Lanning v. SEPTA)

4. Verbalization of a valid business justification for the scoring procedure in question. (Burden of Production)

5. Evidence that the organization made a reasonable effort to make rational hiring decisions but presented no concrete validation evidence. (Relaxed Validation Requirements)

\section{Attorney Knowledge Items.}

1. Evidence that (1) a suitable job analysis was conducted recently and (2) a competent and reputable professional was used to construct the selection test. (High Test Quality)

2. Evidence that the scoring method used was (1) appropriate and recommended by the test professionals who constructed the test and (2) could successfully select applicants who can perform better on the job. (Proper Scoring)

3. Evidence that (1) the content of the test was found to be related to and representative of the content of the job and (2) the procedure of the test was similar to the procedures required by the job. (High Test Standards)

4. Evidence that (1) the hiring position's job analysis was conducted 5 years ago (2) and that the selection test was purchased from an outside distributer. (Low Test Quality)

5. Evidence that the scoring method used was minimally predictive of top job performers. (Improper Scoring)

6. Evidence that organization did not conduct a validation study. (Low Test Standards)

\section{Adverse Impact Reduction Strategy Items.}

1. Evidence that the organization used alternative measurement methods (e.g., interviews, work samples, assessment centers or situational judgment tests) instead of paper-and-pencil testing.

2. Evidence that the organization used alternative modes of test item presentation (e.g., video, interactive computer based media) rather than multiple choice or paper-and-pencil testing.

3. Evidence that the organization used an unproctored internet test (an internet-based test completed by a candidate without a traditional human proctor) to screen applicants 
4. Evidence that the organization used specific measures of ability rather than general measures of ability.

5. Evidence that the organization used test-score banding instead of selecting employees top-down. This method statistically groups similar scores within given ranges (e.g. 100-95, 95-90), and treats them as equivalent scores.

6. Evidence that the organization used test score banding and also used a minority preference (e.g. selected minority applicants) within the bandwidth.

7. Evidence that the organization gave more weight to contextual performance predictors (e.g., helping coworkers, dependability, commitment, personality) than to task performance (e.g. how well someone completed a work related task).

8. Evidence that verbal ability requirements were reduced to an extent supported by the job analysis.

9. Evidence that items were written to be free of content that would be more familiar or less familiar to a particular subgroup.

10. Evidence that the organization removed items that demonstrated different scores for subgroups.

11. Evidence that the organization removed or relaxed time limits for completion of the selection procedure.

12. Evidence that the organization allowed applicants to reapply for the job if they were rejected.

13. Evidence that the organization provided a testing orientation and preparation program prior to selection testing.

14. Evidence that the organization made efforts to increase and retain the number of qualified minority and female applicants in the hiring pool.

15. Evidence that the organization provided explanations for why the particular testing procedures were being used.

16. Evidence that the organization used screening devices with less adverse impact early in the selection process and those with greater potential for adverse impact later in the process.

17. Evidence that the organization completely removed testing components that have the highest potential for adverse impact but also the most valid prediction of job performance.

\section{Part III. Demographic Questionnaire.}

1. What is your age? (Fill in the blank)

2. What is your gender?

$\square$ Male

$\square$ Female

3. What is your race? (Choose one)

$\square$ White (Non-Hispanic)

African-American

Hispanic 
Asian

Native American

Other (Fill in the Blank)

4. Please select the option that best describes you.

$\square 3^{\text {rd }}$ Year Law Student

$\square$ Law School Graduate but have not yet passed the ABA Bar Exam

$\square$ Law School Graduate, passed the ABA Bar Exam, but awaiting employment

$\square$ Law School Graduate, passed the ABA Bar Exam, but not pursuing a legal career

$\square$ Practicing attorney

$\square$ Judge

5. In what year did you obtain your law degree? If you have not yet graduated please select the year you expect to graduate. (Fill in the blank)

6. In what state do you practice law? (Fill in the blank)

7. How long have you been practicing law? (Fill in the blank)

8. What type(s) of law have you practice(d)? (Check all that apply)

$\square$ Civil Rights Law

$\square$ Corporate/Securities Law

$\square$ Criminal Law

$\square$ Education Law

$\square$ Employment/ Labor Law

$\square$ Environmental/Natural Resources Law

$\square$ Family Law

$\square$ Health Law

$\square$ Immigration Law

$\square$ Intellectual Property Law (Patent, Copyright etc.)

$\square$ International Law

$\square$ Real Estate Law

$\square$ Tax Law

Other (Fill in the Blank)

9. Have you ever dealt with an employment dispute regarding employment selection? (Yes or No)

(If Yes) Which party did you represent?

$\square$ Plaintiff/Claimant

$\square$ Defendant/Respondent

10. Have you ever been involved in any type of Title VII dispute? (Yes or No) (If Yes) Which of the following best describes your role?

$\square$ Expert 
$\square$ Witness

$\square$ Defendant

$\square$ Plaintiff

$\square$ Defendant's counsel

$\square$ Plaintiff's counsel

(If Yes) Which protected group(s) was involved? (Check all that apply)

$\square$ Race/Color/National Origin

$\square$ Sex

$\square$ Religion 